\title{
The Happiness Gap in Eastern Europe*
}

\author{
Simeon Djankov ${ }^{1}$, Elena Nikolova ${ }^{2}$, and Jan Zilinsky ${ }^{3}$ \\ ${ }^{1}$ New Economic School and National Research University Higher School of Economics \\ ${ }^{2} \mathrm{EBRD}$ \\ ${ }^{3}$ Peterson Institute for International Economics
}

September 2015

\begin{abstract}
Citizens in Eastern Europe are less satisfied with life than their peers in other countries. This happiness gap has persisted over time, despite predictions to the contrary by earlier scholars. It holds after controlling for a variety of covariates, such as the standard of living, life expectancy and Eastern Orthodox religion. Armed with a battery of surveys from the early 1990s to 2014, we argue that the happiness gap is explained by how citizens in post-communist countries perceive their governments. Eastern Europeans link their life satisfaction to higher perceived corruption and weaker government performance. Our results suggest that the transition from central planning is still incomplete, at least in the psychology of people.
\end{abstract}

\footnotetext{
${ }^{*}$ This paper is written as part of a symposium: Ukraine: Escape from Post-Soviet Legacy? The authors would like to thank an anonymous referee, Abhijit Banerjee, Erik Berglöf, Andrew Clark, Yuriy Gorodnichenko and Gérard Roland for helpful comments. The views expressed in this paper are those of the authors only and not necessarily of the EBRD.
} 


\section{Introduction}

How do large-scale economic and political transformations, such as the collapse of communism in the former Soviet bloc, affect perceived welfare? Along many dimensions, the transition process can be deemed a success. Most countries in the region have experienced sustained economic growth since the mid-1990s, many have become fully fledged democracies (and some members of the European Union), and technological advancement and freedom to travel abroad have improved living standards tremendously. Not everyone has fared well, however: in Ukraine PPP-adjusted GDP per capita decreased from USD 10,490 in 1990 to USD 8,267 in 2014. ${ }^{1}$ Could this disparity in economic performance explain the dip in happiness experienced by some of the post-communist countries?

The answer seems to be negative: income gains in the post-communist region have failed to translate into convergence in life satisfaction. Although scholars have acknowledged that transition has been an unhappy process (for example, Guriev and Zhuravskaya, 2009), the expectation was that economic and political reform would eventually be rewarded. This prophecy has not come true yet: for example, Ukraine and Russia are consistently found near the bottom of rankings of life satisfaction, with scores lower than those of countries like Bangladesh and Senegal. Armenians, Bulgarians, Georgians, Moldovans and Serbians are less happy than Peruvians and Indians. Hungarians are less happy than Kosovars and Mongolians. Why, then, as economic advancements are materializing for most countries, are the psychological benefits lagging behind?

In this paper, we tackle this question by building a comprehensive time series of four different surveys covering 82 countries from the early 1990s to 2014. Our analyses confirm that post-communist economies are systematically unhappier than their advanced and developing counterparts in the rest of the world. This happiness gap holds even after accounting for a variety of factors, such as the log of per capita income, life expectancy and Eastern Orthodox religion. In fact, we find that the income-satisfaction gradient is similar for transition and non-transition countries. Moreover, while the happiness gap did narrow somewhat between 1990 and the early 2000s, it has stayed remarkably persistent throughout the whole transition period.

\footnotetext{
${ }^{1}$ The data are in constant international 2011 dollars. See http://data.worldbank.org/indicator/NY.GDP.PCAP.PP.KD.
} 
Since cross-country regressions may suffer from endogeneity and data heterogeneity, we complement our analyses with individual-level regressions from the second round of the Life in Transition Survey (LiTS), conducted in 2010 by the EBRD and the World Bank. In addition to having the most comprehensive coverage of the transition region (29 countries), the survey also includes Turkey and five Western European comparators. As a second check on our results, we combine a new $o b$ jective index of municipal corruption in Bulgaria (collected by Nikolova and Marinov (2015) and covering the period 2004-2005) with individual data from the first round of the Life in Transition Survey (completed in 2006). However, just as in earlier work, an important caveat is that while surveys can tell us a lot about average differences and which factors weaken or even eliminate empirical regularities, the relationships studied in this paper are less likely to yield causal interpretation.

Our explanation focuses on the importance of perceived corruption and government performance for life satisfaction in Eastern Europe. This result fits the Ukrainian case particularly well, since the country is consistently ranked among the most corrupt in the world. Accounting for political corruption and quality of governance eliminates the gap in subjective well-being completely in our cross-country regressions, while including variables capturing government performance and the importance of political connections and breaking the law reduces it substantially when we look at individual-level data. At the same time, we find that perceived corruption in various public services has little effect on life satisfaction both in our cross-country and individual-level regressions. These findings suggest that while Eastern Europeans have grown used to tolerate petty bribery, they are more strongly affected by government efficiency and political corruption.

Furthermore, our results indicate that Eastern Europeans are unhappier not because they are more likely to internalize government behavior, but because they have experienced more corruption and poor governance relative to their peers in Western Europe. This is salient in countries such as Ukraine, as in many (even democratic) transition countries elites associated with the former communist regime have not only remained in power, but have also used their political connections to amass considerable wealth (Aslund and Djankov, 2014).

We also find that Eastern Orthodox religion explains around $30 \%$ of the happiness gap. This 
suggests that large-scale economic and political changes may be particularly salient for declining life satisfaction in countries with a large Eastern Orthodox population, including Belarus, Bulgaria, Georgia, Macedonia, Moldova, Montenegro, Romania, Russia, Serbia and Ukraine. We hypothesize that the negative effect of a large Eastern Orthodox population on happiness may be due to the emphasis of this religion on fasting, reflection and prayer.

Our work relates to three strands of the literature. First, our findings resonate with the extensive literature on the link between income, economic growth and life satisfaction (Clark et al., 2008; Deaton, 2008; Easterlin, 1995; Stevenson and Wolfers, 2008). Second, a smaller but growing literature has studied how life satisfaction is affected by economic and political changes in Eastern Europe (Easterlin, 2009; Guriev and Zhuravskaya, 2009; Sanfey and Teksoz, 2007), China (Easterlin et al., 2012; Graham et al., 2015), Latin America (Graham and Lora, 2010) and Africa (Graham and Nikolova, 2013). And third, we contribute to a rich literature on the consequences of corruption for welfare (Bertrand et al., 2007; Mauro, 1995; Pande and Olken, 2012; Rose-Ackerman, 1999; Shleifer and Vishny, 1994).

Our contribution to previous work is four-fold. First, the paper highlights the fact that economic and political transitions may have persistent effects that go beyond objective well-being and democracy. This is important in view of the renewed attention to the question of benefits from transition not only in Ukraine, but also as a warning to other countries undergoing reform in Africa, Asia and Latin America. Second, understanding the trends in subjective life evaluation is particularly salient in emerging countries such as Ukraine, as signs of reform backlash bring into question the sustainability of pro-growth policies and the resilience of young economic and political institutions. ${ }^{2}$ Third, our results imply that corruption and poor government performance may have overarching consequences for both objective welfare (reflected in standard economic indicators) as well as subjective well-being. ${ }^{3}$ And finally, the study brings evidence on the importance of counterfactuals: apparently citizens in Eastern Europe evaluate improvements in their well-being not only relative to themselves and to others in the past, but also relative to other countries (Becchetti

\footnotetext{
${ }^{2}$ On reform fatigue in the transition region, see Aslund and Djankov (2014); Denisova et al. (2010, 2012).

${ }^{3}$ See Banerjee et al. (2012) for a discussion on the social psychology of corruption.
} 
et al., 2013; Ljungqvist and Uhlig, 2000).

The rest of the paper is organized as follows. The next section puts the paper in the context of the broader literature. Section 3 describes the data, section 4 presents the results, section 5 conducts robustness checks, and section 6 concludes.

\section{Previous Literature}

A large literature has looked at the determinants of subjective well-being in both advanced and developing countries. The growing interest in this topic has been driven by extensive evidence that surveys of life satisfaction can generally yield meaningful and consistent measures of people's welfare (Clark and Senik, 2011; Nikolova and Sanfey, 2014). Research on life satisfaction has also been utilized by policy makers, for example by the OECD which routinely produces cross-country measures of happiness. ${ }^{4}$

Much of the discussion in the existing literature has focused on the importance of income. A body of early work claimed that average income is not related to subjective well-being across countries and within individual countries over time. At the same time, cross-sectional withincountry results seemed to suggest that the two variables are positively correlated (Easterlin, 1995; Layard, 1980). Scholars have tried to reconcile these findings by stressing the importance of relative income comparisons to others or to oneself in the past (Clark et al., 2008). However, recent research has shown that income and happiness are related both in the time series and in the cross-section, but that this relationship is log-linear, rather than simply linear, as hypothesized by the earlier literature (Deaton, 2008; Stevenson and Wolfers, 2008). ${ }^{5}$

One implication of this literature is that life satisfaction should rise as personal incomes grow, both within and across countries. However, an important puzzle relates to countries which have

\footnotetext{
${ }^{4}$ See also Stiglitz et al. (2009). We use happiness, subjective well-being and life satisfaction interchangeably, although arguably life satisfaction is related to an overall life evaluation, while happiness is more experiential.

${ }^{5}$ Deaton (2008) uses a country-level panel built from the Gallup World Poll surveys. Stevenson and Wolfers (2008) conduct both cross-country and within-country analyses and, in addition to the Gallup data, utilize the World values Survey, the Pew Global Attitudes Survey, the Eurobarometer Survey (for Europe only), and separate surveys for Japan and the United States.
} 
undergone large-scale economic transformation, such as those in Africa, China or the former Communist bloc. Despite sustained economic growth and a large improvement in living conditions, life satisfaction in these countries has stagnated.

Different explanations for the existence of this happiness gap have been proposed. In China, Easterlin et al. (2012) show that, just like in Eastern Europe, happiness declined considerably between 1990 and 2005 (with some recovery by 2010) despite strong economic growth. This was due to rising unemployment, dissolution of the social safety net, and growing inequality. Graham et al. (2015) find that those Chinese who lack security or have long working hours and high workforce stress are particularly unhappy, with similar patterns for the case of mental health. In Africa, Graham and Nikolova (2013) demonstrate that while information technology and financial inclusion tools such as mobile banking have increased general well-being, they are also a source of stress and anger for some groups. In the cross-country setting, Deaton (2008) shows that higher growth is associated with lower life satisfaction on average, something which Graham and Lora (2010) have labeled the "paradox of unhappy growth."

In the post-communist world, citizens are unhappy because transition brought about: (1) unfairness and inequality; (2) deterioration of public goods; (3) income volatility and increased uncertainty; and (4) changes in aspiration levels (Guriev and Zhuravskaya, 2009). ${ }^{6}$ Sanfey and Teksoz (2007) also stress the negative link between inequality and happiness in post-communist countries, as well as the role of incomplete market-oriented reforms. Inglehart et al. (2008) argue that the collapse of communism may have left a spiritual vacuum, as belief in the communist ideology may have been akin to religious observance. More generally, scholars predicted that this happiness gap would recover as transition countries catch up economically to their Western peers.

In this paper, we build on this earlier work by answering two questions. First, has the life satisfaction gap between transition and non-transition countries narrowed over time? And second,

\footnotetext{
${ }^{6}$ Similarly, Easterlin (2009) argues that loss aversion is important: stagnating labor market conditions and a deteriorating social safety net are responsible for the lack of recovery in life satisfaction in the transition region. An aversion to uncertainty is observed even in advanced market economies: using a large voluntary on-line survey of more than 20,000 workers in Spain, Guzi and de Pedraza Garca (2015) document a negative correlation between subjective well-being and job insecurity. While Blanchflower and Freeman (1997) document that acceptance of pay differentials across professions rose in the early 1990s in Hungary and Poland, Grosfeld and Senik (2010) show that tolerance of inequality actually decreased in Poland in the late 1990s.
} 
if the gap has not closed, what could explain its persistence? At first sight, the answers to these questions are ambiguous. On the one hand, we may expect that those in the former Eastern bloc have become more sanguine, due to adaptation to the volatility, competitive pressures, and other less desirable aspects of market economies. In addition, life satisfaction may have increased as incomes in transition economies have grown considerably. On the other hand, unpleasant memories and disappointments with the initial (and in many countries still incomplete) transition process may have persisted, highlighting the psychological costs of large-scale transformations. ${ }^{7}$ We tackle these questions in the remainder of the paper.

\section{Data}

Our analysis exploits four complementary data sets which jointly cover the period from the early 1990s until 2014, with the majority of observations from the post-2004 period. We describe each of the data sets briefly below, and Table 1 provides more details on the countries and years covered.

\subsection{Pew}

Our data come from the Pew Global Attitudes Survey, a nationally representative survey administered since 2001 by the Pew Research Center. Sample sizes range between 700 to 1,500 interviews per country, with 1,000 interviews the most common sample size. The survey covers between 5 and 42 countries per year. The interviews are conducted both by telephone and face-to-face. Telephone surveys use the random digit dialing methodology, and employ three different sampling patterns, depending on landline and cellphone use in a particular country: (1) cell and landline; (2) cell only; and (3) landline only. Face-to-face surveys use random samples based on multi-stage, cluster designs. In particular, large territorial units (similar to states or counties in the US) are selected first, followed by a selection of smaller territorial units, and finally city blocks or villages. At the latter stage, interviewers visit a selection of addresses, either selected randomly from a list or following a

\footnotetext{
${ }^{7}$ Recent evidence from Germany (Pfeifer and Petrunyk, 2015) shows that the East-West satisfaction gap within the country has persisted, even accounting for differences in income and unemployment. Our paper explores the happiness gap across countries.
} 
random walk. At each address, adult respondents are selected randomly.

\subsection{Eurobarometer}

We also make use of the Eurobarometer, a nationally representative survey conducted since 1973 by the European Commission. The survey includes approximately 1,000 face-to-face interviews per member state (with the exception of Germany (1,500 interviews), Luxembourg (500 interviews), and the UK (1,300 interviews, including 300 in Northern Ireland)). It is conducted between 2 and 5 times a year. The Eurobarometer survey follows a multi-stage, random probability sample design. In the first stage, Primary Sampling Units, stratified by region (following the EU NUTS

classification system) and level of urbanity, are selected with a probability proportional to size. In the second stage, a cluster of addresses is selected from each sampled primary sampling unit, using standard random route procedures, beginning with an initial address selected at random. In each household, an adult respondent is then selected by a random procedure, such as the first birthday method. Up to two recalls are made to obtain an interview with the selected respondent.

\subsection{European Values Study}

The European Values Study, first conducted in 1981, is a nationally representative longitudinal survey carried out under the responsibility of the European Values Study Foundation. The fourth wave (completed in 2008) covered 47 European countries and regions and 70,000 respondents using face-to-face interviews. A representative multi-stage or stratified random sample of the adult population of the country aged 18 and older was used (except Armenia (15+) and Finland (18 to 74)). 1,500 respondents per country were interviewed, except Northern Cyprus and Northern Ireland (500), Iceland (808), Cyprus (1,000), Ireland (1,013), Norway (1,090), Finland (1,134), Sweden $(1,187)$, Switzerland $(1,272)$, France (random sample of 1501 and two additional quota samples: 1,570) and Germany (diproportional sample of 1,004 in East Germany and 1,071 in West Germany). 


\subsection{Life in Transition Survey}

The Life in Transition Survey (LiTS) is a nationally representative survey which covers 29 postcommunist countries. ${ }^{8}$ It was conducted by the European Bank for Reconstruction and Development and the World Bank in 2006 and 2010. In 2010, the survey also included for comparison purposes five Western European countries (France, Germany, Italy, Sweden, United Kingdom) and Turkey. Respondents (aged 18 and above) are drawn randomly, using a two-stage sampling method with primary and secondary sampling units. The primary sampling units are electoral districts, polling station territories, census enumeration districts or geo-administrative divisions. Each country has a minimum of 50 primary sampling units with each primary sampling unit containing around 20 responding households (for a total of approximately 1,000 observations), with the exception of Russia, Ukraine, Uzbekistan, Serbia and Poland (in the 2010 wave only, where 75 primary sampling units containing around 20 responding households each were drawn, for a total of approximately 1,500 observations).

The head of the household or another knowledgeable household member answered the Household Roster and questions about housing and expenses. All other modules ${ }^{9}$ were answered by a randomly drawn adult (over 18 years of age) from the household with no substitutions possible, using a minimum of three repeat visits if an interview could not be conducted. When running specifications with individual-level data from the LiTS, we supplement the survey data with external data on the geographic characteristics of primary sampling units from Nikolova and Simroth (2015) (latitude, longitude and altitude, where the latter is only available for the 2010 data). The availability of such geo-referenced data on the precise location of each respondent, along with the inclusion of all transition countries (except Turkmenistan), are the two major strengths of the LiTS as compared to the other surveys in our sample.

\footnotetext{
${ }^{8}$ These are Albania, Armenia, Azerbaijan, Belarus, Bosnia and Herzegovina, Bulgaria, Croatia, Czech Republic, Estonia, Georgia, Hungary, Kazakhstan, Kyrgyz Republic, Latvia, Lithuania, FYR Macedonia, Moldova, Mongolia, Poland, Romania, Russia, Serbia, Slovak Republic, Slovenia, Tajikistan, Ukraine, Uzbekistan, Kosovo (2010 only) and Montenegro.

${ }^{9}$ For instance, in the 2010 wave, the other modules are: Attitudes and Values; Climate Change; Labor, Education and Entrepreneurial Activity; Governance, and Miscellaneous Questions.
} 


\subsection{Dependent variable}

We construct our dependent variable using answers to the following survey questions:

- Pew: "Here is a ladder representing the ladder of life. Suppose the top of the ladder represents the best possible life for you and the bottom, the worst possible life. On which step of the ladder do you feel you personally stand at the present time?", with answer options from 1 to 10.

- Eurobarometer: "On the whole, are you very satisfied, fairly satisfied, not very satisfied, or not at all satisfied with the life you lead?", with answer options very satisfied (1); fairly satisfied (2); not very satisfied (3) and not at all satisfied (4).

- European Values Study: "Taking all things together, how happy are you?", with answer options 1 (very happy); 2 (quite happy); 3 (not very happy); and 4 (not at all happy)

- Life in Transition Survey: "All things considered, I am satisfied with my life now", with answer options 1 (strongly disagree); 2 (disagree); 3 (neither disagree nor agree); 4 (agree); and 5 (strongly agree). ${ }^{10}$

In order to make the life satisfaction responses comparable across countries and surveys, we recode all four questions as a dummy variable, with 0 meaning "dissatisfied," and 1 meaning "satisfied." We opt for this approach instead of standardizing all responses, since standardization within a survey is sensitive to the types of countries included in the survey sample. For instance, standardizing responses in a survey with many happy countries and few unhappy ones will lead to disproportionately penalizing the latter group. In the regressions below, we account for differences in scales and wording by including survey dummies in all specifications. The coding procedure adopted for our dependent variable is as follows:

- Pew: We classify the people on the seventh rung (of ten) on the ladder, or higher, as "satisfied."

\footnotetext{
${ }^{10}$ In all surveys, we drop respondents who answered "Don't know" in our analyses below.
} 
- Eurobarometer: We add the share of respondents who say they are "very satisfied" and those who are "fairly satisfied" and count these respondents as "satisfied."

- European Values Study: We count those who are "very happy" and "quite happy" as "satisfied."

- LiTS: We count the number of respondents who either agree or strongly agree with the statement to compute the share of respondents who are satisfied.

Our pooled sample consists of 82 countries. Unreported calculations show that life satisfaction responses are very highly correlated across surveys, with correlation coefficients above 0.9. Survey answers least correlated with the rest come from the European Values Study: that may be the case since this survey asked respondents about happiness, and the other three surveys asked about satisfaction.

\subsection{Preliminary evidence}

To get a sense of the patterns in the data, in Figure 1 we plot the evolution of the "share satisfied" separately for Denmark, the old European Union countries, the Eastern European economies, Bulgaria and Ukraine, between 2004 and 2014. ${ }^{11}$ The figure shows that while nearly all respondents in Denmark are satisfied with life, the corresponding figure for Ukraine is less than $40 \%$ throughout the period. On average, the happiness gap between the transition region and those countries which are part of the "old EU" is between 13-32\%. Moreover, the figure shows that the (unconditional) happiness gap has changed little over time.

The diversity within the Eastern European group is visible in Table 2, which computes the average satisfaction in each country using all years and surveys. The happiest country in the transition region is Slovenia, where around $82 \%$ of the population report being satisfied with life, which is very similar to the happiness levels in advanced countries such as the UK and Austria. Likewise, the satisfaction rates in the Czech Republic and Estonia are $77.1 \%$ and $71.8 \%$, respectively.

\footnotetext{
${ }^{11}$ This graph excludes the data on happiness from the European Values Study.
} 
The least happy transition countries are Ukraine (31.0\% satisfied) and Russia (33.8\% satisfied), whose happiness is comparable to that of Tunisia, Pakistan and Jordan. At least $50 \%$ of respondents seem to be satisfied in Central Asia, while in South-Eastern Europe this figure ranges from 67.2\% for Croatia to $38 \%$ for Bulgaria.

Figure 2 shows the unconditional correlation between satisfaction rates and the log of per capita GDP (each point represents a single survey-country-year observation). In both Eastern European and non-Eastern European countries, the two variables appear to be positively correlated. However, the majority of Eastern European economies (shown in color), appears below the 45 degree line, indicating that other variables must explain the abnormally low happiness levels in this region. ${ }^{12}$

In the next section, we examine these patterns more systematically via regression analysis.

\subsection{Independent variables: cross-country regressions}

The main covariates come from the following sources. PPP-adjusted GDP per capita is from the October 2014 release of IMF's World Economic Outlook. The Corruption Perception Index is Transparency International's proxy for the incidence of corruption. Data on government effectiveness come from the World Bank Worldwide Governance Indicators. Life expectance data are from the World Bank. Inequality data (Gini coefficients) come from the latest available observations from the Luxembourg Income Study (LIS) or PovcalNet databases (these readings must be interpreted with caution because compliance with surveys is uneven and temporal coverage is not always satisfactory). In a few cases, OECD income inequality estimates were used. Regional classification identifiers follow the World Bank.

The data on religious affiliation are from the World Religion Dataset. We choose to focus on the share of the population belonging to the Eastern Orthodox religion. We hypothesize that large-scale economic and political changes may be particularly salient for declining life satisfaction in countries with a large Eastern Orthodox population, due to the emphasis of this religion on reflection and

\footnotetext{
${ }^{12}$ In the figure, $58.2 \%$ of Eastern European observations are below the 45 degree line. However, given that this is an unconditional scatter plot, differences among surveys are not visually reflected.
} 
prayer. ${ }^{13}$ In related work, Barro and McCleary (2003) find that a higher share of Eastern Orthodox population in a country is correlated with weaker economic growth. A number of post-communist countries have Orthodoxy as the prevalent religion, such as Belarus, Bulgaria, Georgia, Macedonia, Moldova, Montenegro, Romania, Russia, Serbia and Ukraine. Several countries in the remainder of the sample, for example Cyprus and Greece, do too, making empirical tests possible.

\subsection{Independent variables: individual-level regressions}

Our individual-level regressions use the Life in Transition Survey covering 2010 (for the analysis using both transition and non-transition countries) and 2006 (for the analysis using Bulgarian corruption data). The independent variables included in these specifications include respondent age; the square of respondent age; respondent's self-assessed health; gender; and marital status. We also control for a range of individual socio-economic characteristics (education dummies, income and whether the individual was employed in the past 12 months) and parental background (father's education and whether the respondent or his parents/grandparents were injured, killed or displaced during World War II). To capture a respondent's attitudes toward corruption and government effectiveness, we include survey-based variables measuring corruption perceptions. The first variable is constructed from a question proxying the degree to which the respondent believes that people like him have to make unofficial payments or gifts when using a range of public services, such as interacting with the road police or going to courts for a civil matter. A dummy for whether the respondent believes that effort and hard work, or intelligence are skills are most important for success in their country (as opposed to political connections and breaking the law) is also used. Finally, we construct a variable on how the respondent rates the overall performance of local and national government.

In the analyses using LiTS 2006, we use only the data for Bulgaria and in addition to the survey

\footnotetext{
${ }^{13}$ The Eastern Orthodox church came into existence in 1054 when it broke away from the Roman Catholic church. The main doctrinal issue has been the dissagreement on the supremacy of the Pope. In addition, Eastern Orthodox Christianity stresses a life that is focused on fasting, worship and prayer. The following is an example of such a prayer: "Lord Jesus Christ, Son of God, have mercy on me, a sinner." Prayers are to be repeated many times in order to enable the believer to focus fully on God. Moreover, monasticism is a central part of the Eastern Orthodox faith.
} 
variable capturing corruption perceptions, we use an objective corruption index as described below. LiTS 2006 contains no information about the respondent's marital status, family victimization during World War II, or government performance so these three variables are omitted. Survey weights, which ensure that the data are representative at the country level, are used in all specifications.

\subsection{Objective data on corruption from municipal audits in Bulgaria}

We supplement our survey-based measures of corruption perceptions with an objective index of corruption at the municipal level for Bulgaria collected by Nikolova and Marinov (2015). Objective corruption data is still rare in the literature, so unfortunately we limit our analyses to a single country. We make use of unique data set on the use of disaster aid distributed to local governments in Bulgaria following unexpected torrential rains which led to flooding in 2004 and 2005. What was not known at the time of disbursement was that an independent national auditing watchdog would be summoned in spring 2006 to issue detailed reports on how the money was used for 227 out of 257 municipalities receiving assistance. ${ }^{14}$ The resulting public reports, released in early September 2006, chronicle a variety of infringements including: (1) contracts not awarded to the highest bidder or no bidding, (2) money channeled for the repair of buildings experiencing no damage, and (3) money given for no work. Following the approach in Ferraz and Finan (2008, 2011), we use this information to create an objective - as opposed to a perception-based - measure of corruption, which sums all the infringements recorded in a municipality between 2004 and 2005 .

We exploit the fact that the first round of the Life in Transition survey was conducted in Bulgaria in late September 2006, shortly after the audit reports were publicized extensively in the media. In order to combine the LiTS and the Nikolova and Marinov (2015) corruption data set, we match each primary sampling unit in the survey to its corresponding municipality. However, an important caveat is that the results focusing on Bulgaria should be interpreted as suggestive only. Due to its sampling design which uses random sampling at the primary sampling unit, rather than municipal, level, the number of municipalities covered in the LiTS is small (37).

\footnotetext{
${ }^{14}$ These municipalities comprised $96.8 \%$ of disbursed funds.
} 


\section{Results}

\subsection{Cross-country panel results}

To investigate the drivers of differences in life satisfaction between transition and non-transition countries, we run cross-country OLS regressions of the following type:

$$
\text { Satisfaction }_{i s t}=\alpha_{i s t}+\beta(\mathrm{EE})_{i}+\boldsymbol{X}_{\boldsymbol{i t}} \delta+\boldsymbol{S}_{\boldsymbol{s t}} \gamma+\mu_{t}+\epsilon_{i s t}
$$

where for each country $i$ in survey $s$ and time period $t,(\mathrm{EE})_{i}$ is a dummy for whether the country is an Eastern European country, $\boldsymbol{X}_{\boldsymbol{i}}$ is a vector of controls (ln GDP per capita; share of population that are Eastern Orthodox; and life expectancy), $\boldsymbol{S}_{\boldsymbol{s} \boldsymbol{t}}$ is a vector of survey dummies (which controls for differences in the wording and scale of life satisfaction questions), $\mu_{t}$ are year dummies, and $\epsilon_{i s t}$ is the error term. We cluster the standard errors at the country level.

In column (1) of Table 3, we regress our percent satisfied dummy on the logarithm of per capita GDP, a transition country dummy, and survey wave and time dummies. The coefficient estimates imply that a 10\% increase in GDP per capita increases average life satisfaction by around 1.4 percentage points, while residents of transition countries are on average 10.4 percentage points less satisfied. These point estimates change little when we include life expectancy (column 2). As hypothesized earlier, we find that countries with a higher Eastern Orthodox population are less happy (column 3). In fact, comparing the coefficients on the Eastern European dummy in columns (2) and (3) suggests that the inclusion of Eastern Orthodox religion decreases the happiness gap by about $30 \%$.

One interpretation of the results in columns (1) - (3) is that the effect of log per capita income is weaker in the transition region. To test this, we break the sample into Eastern European countries (column 4) and non-Eastern European countries (column 5). To avoid omitted variable bias arising from slow-changing country characteristics such as culture or geography, we also include country 
fixed effects. While the coefficient on log per capita income appears slightly weaker in the nonEastern European sample, a test for the equality of coefficients indicates that the two coefficients are not statistically different from each other. In unreported results, we also included an interaction between the Eastern Europe dummy and log income per capita (along with country dummies), which is insignificant.

In sum, Table 3, demonstrates that citizens in post-communist countries (and particularly those that belong to the Eastern Orthodox religion) are significantly less happy compared to those in other countries. How has this happiness gap changed over time? Figure 3 plots predicted satisfaction rates from re-running the specification in column (1) (controlling for the logarithm of income per capita) along with interactions between the Eastern Europe dummy and dummies for three broad time periods: 1990-2000; 2001-2007; and 2008-2014. The figure shows that although life satisfaction in the transition region has improved since the 1990s, happiness levels in the post-communist world have stagnated since the early 2000s (conditional on changes in income). In other words, there is no evidence that the happiness gap is closing, as predicted by earlier scholars.

In Table 4, we investigate the mechanism behind the patterns identified in Table 3. Column (1) replicates the specification in column (3) of Table 3 but only for those observations where country-level corruption perception data are available. This sample restriction then translates into a direction comparison with the regression in column (2), where we include the corruption perception index as well (0 signifies that the country is completely corrupt, and 100 that there is no corruption). A one-point increase in the corruption score increases life satisfaction by around 0.25 percentage points, which is a strong effect. More importantly, differences in corruption (perceptions) between Eastern European and non-Eastern European countries seems to eliminate completely differences in life satisfaction between the regions.

One potential concern is that the corruption index may proxy for other variables, such as the overall business environment. We test whether this is the case in column (3), which instead of corruption, includes an average of selected Doing Business Indicators. Specifically, we include the mean distance to frontier for starting a business, construction, registering property, paying taxes, 
and enforcing contracts. For definitions, see Djankov et al. (2002) and Botero et al. (2004). The inclusion of this variable does not affect the significance of the Eastern Europe dummy, while rendering its own coefficient insignificant. ${ }^{15}$ In column (4), we substitute the corruption index with alternative governance proxies (from the Worldwide Governance Indicators Database): (1) government effectiveness; (2) regulatory quality; and (3) rule of law. Consistent with our results in column (1), only government effectiveness matters. In other words, citizens from post-communist countries are not unhappy because the overall business or regulatory environments in their countries are weak.

\subsection{Individual-level results}

Our individual-level OLS regressions take the following form:

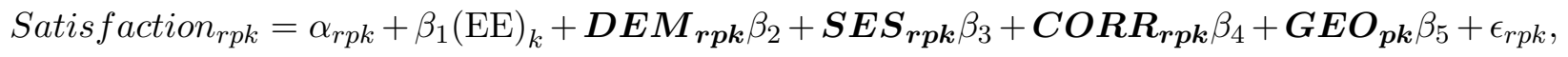

where for each respondent $r$ in primary sampling unit $p$ and country $k,(\mathrm{EE})_{k}$ is a dummy for whether the country is an Eastern European country (with the non-Eastern European category including Italy, France, Germany, Sweden, Turkey and the UK). $\boldsymbol{D} \boldsymbol{E} \boldsymbol{M}_{\boldsymbol{r} \boldsymbol{k}}$ is a matrix of demographic controls: respondent's age; age squared; gender (which takes a value of 1 if respondent is male and 2 if she is female); respondent's self-assessed health on a scale of 1 (very bad) to 5 (very good); marital status (dummy variable taking the value of 1 if the respondent is married and 0 otherwise). $\boldsymbol{S E} \boldsymbol{S}_{\boldsymbol{r} \boldsymbol{k}}$ is a matrix of socio-economic characteristics: dummies for secondary, some post-secondary education, and Bachelor's degree or more (with the omitted category primary or no education), self-reported income (on an income ladder from 1 to 10); dummy for whether the individual was employed in the past 12 months; and parental background (years of father's full-time education, and whether the respondent or his parents/grandparents were injured, killed or displaced during World War II).

\footnotetext{
${ }^{15}$ The Doing Business index does not seem to be simply a proxy for the logarithm of income per capita, as the correlation between the two variables is around 0.3 .
} 
$\boldsymbol{C O R R _ { r k }}$ is a matrix capturing perceptions about corruption and government performance which includes: a corruption index (constructed as an average from several questions probing the degree to which the respondent believes that people like him have to make unofficial payments or gifts when using a range of public services (such as interacting with the road police or going to courts for a civil matter)), on a scale of 1 (never) to 5 (always); a dummy for whether the respondent believes that effort and hard work, or intelligence are skills are most important for success in their country (as opposed to political connections and breaking the law); and an average index of how the respondent rates the overall performance of regional and national government (on a scale of 1 (very bad) to 5 (very good)). $\boldsymbol{G} \boldsymbol{E} \boldsymbol{O}_{\boldsymbol{p} \boldsymbol{k}}$ is a matrix of primary sampling unit controls: latitude, longitude and altitude. Standard errors are clustered at the country level.

As explained above, in the analyses using LiTS 2006 we focus only on Bulgaria. We complement the survey corruption index with an objective corruption variable at the PSU level constructed from municipal audit report following Nikolova and Marinov (2015). Survey weights, which ensure that the data are representative at the country level, are used in all specifications.

Cross-country individual-level results Different sampling procedures, question wording and coverage, along with the absence of individual-level panels, would make the results from pooled multi-survey regressions at the individual level challenging to interpret. We therefore focus soley on LiTS 2010 as it is the only survey that covers all transition countries (with the exception of Turkmenistan), in addition to including six non-transition comparators: France, Germany, Italy, Sweden, Turkey and the UK. Moreover, unlike other surveys, LiTS includes information on the precise geographical location of each primary sampling unit, which allows us to control for fixed locality characteristics (correlated with geography) which may bias our results.

The individual-level results are presented in Table 5. For comparison, column (1) replicates the cross-country results in column (3) of Table 3, but using only the LiTS 2010 data. Due to the small sample (only 34 observations), results should be interpreted with caution. The remaining columns focus on individual-level results. Column (2) shows estimates from a regression of life satisfaction (measured on a scale of 1-5) on several standard covariates: self-reported health, marital status, 
age and its square, gender, education dummies, socio-economic status, and parental background (including family war exposure), along with a dummy which is 1 for transition countries. The point estimate on the transition dummy indicates that the difference in happiness between transition and non-transition citizens is around half a point. This is $14.4 \%$ relative to the mean of the dependent variable, and it explains around 0.42 standard deviations in the variation of life satisfaction. The magnitude of this effect is very similar to that reported by Guriev and Zhuravskaya (2009) for wave 3 of the World Values Survey, which is 1.13 (when happiness is measured on a 1-10 scale). The coefficients on the other variables are in the expected direction. Respondents who are richer, more educated, healthier and married are happier. Life satisfaction and age have a U-shaped relationship, with the nadir occuring at approximately 44 years. Women are marginally happier than men, and parental background seems to matter little, which could be because it is correlated with current socio-economic status.

Column (3) introduces an additional variable: an index of corruption perceptions, constructed as an average from several questions on the degree to which the respondent believes that people like him have to make unofficial payments or gifts when using a range of public services. Unlike in the cross-country specifications, the corruption index is insignificant at the individual level. In column (4) we instead include a related variable: a dummy for whether the respondent believes that effort and hard work, or intelligence are skills are most important for success in their country (as opposed to political connections and breaking the law). We expect that respondents who are dissatisfied with their politicians and unhappy about general corruption are more likely to report that political connections and breaking the law are important for success in life. Column (4) shows that respondents who believe that advancement depends on merit are 0.2 points happier, or $6.6 \%$ relative to the mean of the dependent variable.

We observe a similar pattern in column (5) which includes a variable capturing the interviewee's perception of government performance (averaged at the national and local level), on a scale of 1 (very bad) to 5 (very good). A one-standard deviation increase in the latter variable raises happiness by around $6 \%$ relative to the mean of the dependent variable. Importantly, including both the government performance index and the effort variable in the last column decreases the coefficient 
on the transition dummy from 0.457 in column (1) to 0.361 , or by $21 \%$. We conclude that even when considering individual-level data, citizen perceptions of government performance explain a significant portion of the happiness gap.

In the next two tables, we replicate the analysis in Table 5 separately for the Eastern European (Table 6) and non-Eastern European (Table 7) countries in the sample. Since the sample sizes drop significantly (particularly in Table 7) results should be interpreted as suggestive only. The tables show that income has a stronger effect on life satisfaction in Eastern Europe, while the index of corruption perceptions is insignificant in both cases. Likewise, Eastern and Western Europeans seem to be equally affected by government performance. Interestingly, those who believe that success in life depends on merit are happier in Western Europe. What these results suggest is that Eastern Europeans are not unhappier because they are more strongly affected by government performance or political connections. Rather, the poor perceptions of post-communist governments are likely to have arisen because Eastern Europeans have experienced more corruption and worse governance than their Western counterparts.

Reconciling cross-country and individual-level results on corruption The previous three tables indicate that life satisfaction (both in Eastern and Western Europe) is strongly affected by perceptions of government performance and beliefs on the importance of merit versus political connections and breaking the law. At the same time, perceived corruption in public services does not seem to matter, at least at the individual-level. One reason for this could be measurement error: individuals may just be inept at observing the incidence of illegal activities such as bribery. ${ }^{16} \mathrm{~A}$ broader explanation highlights the importance of different types of corruption for life satisfaction. The corruption proxy in our individual-level regressions focuses only on public services, such as interacting with the road police or going to a court for a civil matter. Eastern Europeans may have gotten used to this "low-level" corruption not only because it existed under communism, but also because many may regard it as necessary in order to get things done better or faster.

In contrast, the Transparency International corruption measure used in the cross-country regres${ }^{16}$ See Olken (2009) for a similar point. 
sions captures both political and administrative corruption. Our results thus suggest that Eastern Europeans are particularly disapproving of government inefficiency and political corruption, possibly because such corruption is regarded as a feature of transition. Under communism, "high-level" bribery was virtually non-existent, as one could not enjoy much more wealth as a politician, given the constraints of command economies.

One implication of this story is that re-running our cross-country regressions with an alternative index capturing corruption only in public services should render the coefficient on the latter variable insignificant. We present results from this exercise in Table 8. We utilize a corruption survey conducted by Transparency International (Corruption Barometer) in 2010 and 2013 in 107 countries. For each country in our data set, we calculate the share of respondents who reported paying a bribe to any of 8 public services in the past 12 months (these services include education, judiciary, medical and health, police, registry and permit services, utilities, tax revenue and/or customs, and land services). We construct a cross-country panel data set by matching the 2010 round of the Corruption Barometer data to the 2010 LiTS data, and the 2013 round of the Corruption Barometer data to the 2014 Pew and Eurobarometer data.

The results in Table 8 are consistent with our theory about the higher importance of political as opposed to public-service corruption. The estimates in columns (1) and (2) exclude the public corruption variable and are very similar to those presented earlier: the Eastern European dummy is strongly significant. In contrast, the proxy for public-service bribery incidence in column (3) is insignificant. Results are similar in column (4) when we also account for the share of the population which is Eastern Orthodox, although the coefficient on the Eastern European dummy is now less precisely estimated. Importantly, this table reconfirms the earlier findings that countries with a larger population belonging to the Eastern Orthodox religion are less satisfied. The inclusion of Orthodox religion also decreases the magnitude of the Eastern European dummy significantly.

Within-country individual results: Bulgaria One issue with both the individual and crosscountry regressions presented thus far is that our proxy for corruption is based on perceptions, rather than objective data. Since happy people may be less likely to believe that corruption is an 
issue, our results may suffer from reverse causality. Not surprisingly, objective corruption indexes are extremely difficult to come by. In our case, we make use of a municipality-level corruption index based on infringements recorded by an independent audit agency and covering the period 2004-2005 collected by Nikolova and Marinov (2015) in Bulgaria. This variable ranges from 0 to 3, with higher values indicating more corruption.

We merge the corruption data with individual-level data on Bulgaria from LiTS 2006 using information on the geographic location of each primary sampling unit in the survey. Because the survey only covers 37 of the audited municipalities (out of a total of 227), the results with the objective corruption index (presented in column (1) of Table 9) should be interpreted with caution. Still, columns (1) and (2) show that both the objective and survey-based corruption measures (the latter extracted from the questions on bribery frequency as in Table 5) are negatively correlated with life satisfaction. Similarly to the pooled country data, column (3) demonstrates that respondents who believe that one needs effort and intelligence to advance are happier. ${ }^{17}$ Combining the latter variable with the subjective corruption index (column 4) or the objective corruption index (column 5) does not significantly change these relationships. One reason for the stronger effect of the public-service corruption index in the case of Bulgaria is that the LiTS was conducted shortly after misappropriation of flood-related funds by many local governments was exposed to the public in early fall 2006.

\section{Robustness}

In unreported results, we probed the robustness of our findings to the inclusion of several additional variables. First, we investigated if the patterns identified in Table 3 change once we account for inequality (measured as a Gini coefficient). Inequality data are notoriously difficult to assemble, so we chose to focus on specifications with the Pew 2014 survey which use only the latest available (and arguably most reliable) inequality data for a sample of 42 countries. In this case, the reference group includes various countries in Asia (South Korea, Malaysia, Vietnam, and others),

\footnotetext{
${ }^{17}$ Data on perceptions of government performance are unfortunately not available in LiTS 2006.
} 
OECD countries like the United States, Chile, Turkey, and Mexico, as well as a few countries in Africa and Latin America. The group of countries classified as Western Europe consists of Greece, Italy, France, Germany, United Kingdom, and Spain. Finally, there are three important Eastern European economies: Ukraine, Poland, and Russia. After including Gini coefficients (for those countries where recent household income surveys exist), the negative correlation between the Eastern European dummy and satisfaction persists.

Second, we re-ran the cross-country specifications in Table 3 using the sample of countries which were part of the 2010 wave of the Life in Transition Survey. As explained earlier, this survey includes 29 transition countries, 5 Western European countries and Turkey. We sequentially included the following three variables. We ran a version in which we accounted for the annual number of sunshine days in each country. In Eastern Europe, the country with the greatest number of sunshine days is Uzbekistan, while that with the least is Lithuania. In a second version, we also controled for perceptions of upward mobility. We constructed country-level indices from answers to the following question in the Life in Transition Survey: "I have done better in life than my parents", measured on a scale of 1 (strongly disagree) to 5 (strongly agree). In a third version, we also included a variable capturing attitudes toward redistribution. The variable is constructed by averaging (at the country level) individual answers to the following question in the Life in Transition Survey: "The gap between the rich and the poor in our country should be reduced," once again measured on a scale of 1 (strongly disagree) to 5 (strongly agree). In all three cases, our results are broadly similar to those in the baseline specification.

\section{Conclusion}

Why are Ukrainians, and Eastern Europeans more generally, unhappy with their lives? Using a battery of surveys covering a multitude of countries over the period from the early 1990s to 2014, along with several measures of corruption and government effectiveness, we argue that this has to do with the poor governance (and the associated citizen perceptions) experienced by much of the region. Since 1989, in many transition countries politics have been dominated by elites associated 
with the old regime, who have managed to accumulate wealth by circumventing the law.

Furthermore, we find that countries with large shares of the population belonging to the Eastern Orthodox religion are unhappier, and that this variable explains around $30 \%$ of the happiness gap. This finding is relevant for several countries in the transition region and beyond, such as Ukraine, Russia, Cyprus and Greece. One possibility could be that Eastern Orthodox countries are more strongly affected by large-scale economic and political changes because their dominant religion emphasizes activities such as reflection, prayer and fasting.

Should we expect this happiness gap to close in the future, as transition countries catch up economically? On the one hand, the economic convergence process is far from certain for everyone: Ukraine's citizens are poorer today relative to 1990. On the other hand, our results suggest that without an improvement in government effectiveness (and the associated citizen perceptions), this is unlikely to happen. The Eastern European economies are not a unique category of countries where the income-happiness relationship identified in the earlier literature does not apply. We show that that the link between income and satisfaction is just as strong across transition economies as in the rest of the sample.

Our results have several important implications for reformers in Ukraine, Eastern Europe more generally, and beyond. First, large-scale societal transformations may bring both economic advances (for some) and long-term psychological costs (for many). Furthermore, dissatisfaction with life may produce reform fatigue, thus threatening the stability of new and vulnerable economic and political institutions. Above all, our results highlight that bribery and poor government performance may have long-term intangible costs that not only transcend a simple economic calculus, but also profoundly affect people's everyday lives. Ukrainian policy makers should thus tackle not only poor economic growth, but also effectively address political corruption. 


\section{References}

Aslund, A. And S. DJAnkov (2014): The Great Rebirth: Lessons from the Victory of Capitalism over Communism, Peterson Institute for International Economics.

Banerjee, A., S. Mullainathan, And R. Hanna (2012): "Corruption," NBER working paper.

Barro, R. J. And R. M. McCleary (2003): "Religion and Economic Growth Across Countries," American Sociological Review, 68, 760-781.

Becchetti, L., S. Castriota, L. Corrado, and E. G. Ricca (2013): "Beyond the Joneses: Inter-country Income Comparisons and Happiness," Journal of Socio-Economics, 45, 187-195.

Bertrand, M., S. Djankov, R. Hanna, and S. Mullainathan (2007): "Obtaining a Driver's License in India: an Experimental Approach to Studying Corruption," Quarterly Journal of Economics, 1639-1676.

Blanchflower, D. G. And R. B. Freeman (1997): "The Attitudinal Legacy of Communist Labor Relations," Industrial and Labor Relations Review, 50, 438-459.

Botero, J. C., S. Djankov, R. La Porta, F. Lopez-de Silanes, and A. Shleifer (2004): "The Regulation of Labor," Quarterly Journal of Economics, 1339-1382.

Clark, A. And C. Senik (2011): "Will GDP Growth Increase Happiness in Developing Countries?" in Measure For Measure: How Well Do We Measure Development?, ed. by R. Peccoud, Paris: STIN.

Clark, A. E., P. Frijters, And M. A. Shields (2008): "Relative Income, Happiness, and Utility: An Explanation for the Easterlin Paradox and Other Puzzles," Journal of Economic Literature, 46, 95-144.

Deaton, A. (2008): "Income, Health, and Well-Being Around the World: Evidence from the Gallup World Poll," Journal of Economic Perspectives, 53-72.

Denisova, I., M. Eller, T. Frye, And E. Zhuravskaya (2012): "Everyone Hates Privatization, but Why? Survey Evidence from 28 Post-Communist Countries," Journal of Comparative Economics, 40, 44-61.

Denisova, I., M. Eller, And E. Zhuravskaya (2010): "What Do Russians Think about Transition?" Economics of Transition, 18, 249-280.

Djankov, S., R. La Porta, F. Lopez-de Silanes, and A. Shleifer (2002): "The Regulation of Entry," Quarterly Journal of Economics, 1-37.

EAsterlin, R. A. (1995): "Will Raising the Incomes of All Increase the Happiness of All?" Journal of Economic Behavior \&5 Organization, 27, 35-47.

(2009): "Lost in Transition: Life Satisfaction on the Road to Capitalism," Journal of Economic Behavior \& Organization, 71, 130-145. 
Easterlin, R. A., R. Morgan, M. Switek, and F. Wang (2012): "China's Life Satisfaction, 1990-2010," Proceedings of the National Academy of Sciences, 109, 9775-9780.

Ferraz, C. And F. Finan (2008): "Exposing Corrupt Politicians: The Effects of Brazil's Publicly Released Audits on Electoral Outcomes," Quarterly Journal of Economics, 123, 703-745.

(2011): "Electoral Accountability and Corruption: Evidence from the Audits of Local Governments," American Economic Review, 101, 1274-1311.

Graham, C. And E. Lora (2010): Paradox and Perception: Measuring Quality of Life in Latin America, Brookings Institution Press.

Graham, C. And M. Nikolova (2013): "Does Access to Information Technology Make People Happier? Insights from Well-Being Surveys from around the World," Journal of Socio-Economics, 44, 126-139.

Graham, C., S. Zhou, and J. Zhang (2015): "Happiness and Health in China: The Paradox of Progress," Brookings Institution Working Paper.

Grosfeld, I. And C. SeniK (2010): "The Emerging Aversion to Inequality: Evidence from Poland 1992-2005," Economics of Transition, 18, 1-26.

Guriev, S. and E. Zhuravskaya (2009): “(Un) happiness in Transition," The Journal of Economic Perspectives, 23, 143.

Guzi, M. And P. De Pedraza Garca (2015): "A Web Survey Analysis of Subjective Well-Being," International Journal of Manpower, 36, 48-67.

Inglehart, R., R. Foa, C. Peterson, and C. Welzel (2008): "Development, Freedom, and Rising Happiness: A Global Perspective (1981-2007)," Perspectives on Psychological Science, 3, $264-285$.

Layard, R. (1980): "Human Satisfactions and Public Policy," Economic Journal, 737-750.

Ljungqvist, L. And H. Uhlig (2000): "Tax Policy and Aggregate Demand Management under Catching up with the Joneses," American Economic Review, 356-366.

Mauro, P. (1995): "Corruption and Growth," Quarterly Journal of Economics, 681-712.

Nikolova, E. And N. Marinov (2015): "Do Public Fund Windfalls Increase Corruption? Evidence from a Natural Disaster," EBRD working paper.

Nikolova, E. And P. SAnfey (2014): "How Much Should We Trust Life Satisfaction Data? Evidence from the Life in Transition Survey," EBRD working paper.

Nikolova, E. And D. Simroth (2015): "Religious diversity and entrepreneurship in transition: lessons for policymakers," IZA Journal of European Labor Studies, 4, 1-21.

Olken, B. A. (2009): "Corruption Perceptions vs. Corruption Reality," Journal of Public Economics, 93, 950-964. 
Pande, R. And B. Olken (2012): "Corruption in Developing Countries," Annual Review of Economics, 4, 479-509.

Pfeifer, C. And I. Petrunyk (2015): "Life Satisfaction in Germany after Reunification: Additional Insights on the Pattern of Convergence," IZA DP No. 9055.

Rose-Ackerman, S. (1999): Corruption and Government: Causes, Consequences, and Reform, Cambridge University Press.

Sanfey, P. And U. Teksoz (2007): "Does Transition Make You Happy?" Economics of Transition, 15, 707-731.

Shleifer, A. And R. W. Vishny (1994): "Politicians and Firms," Quarterly Journal of Economics, 995-1025.

Stevenson, B. And J. Wolfers (2008): "Economic Growth and Subjective Well-being," Brookings Papers on Economic Activity, Spring.

Stiglitz, J., A. Sen, J.-P. Fitoussi, Et AL. (2009): "The Measurement of Economic Performance and Social Progress Revisited," Reflections and overview. Commission on the Measurement of Economic Performance and Social Progress, Paris. 


\section{FIGURES AND TABLES}

Figure 1: Share of satisfied respondents across selected economies, 2004 - 2014

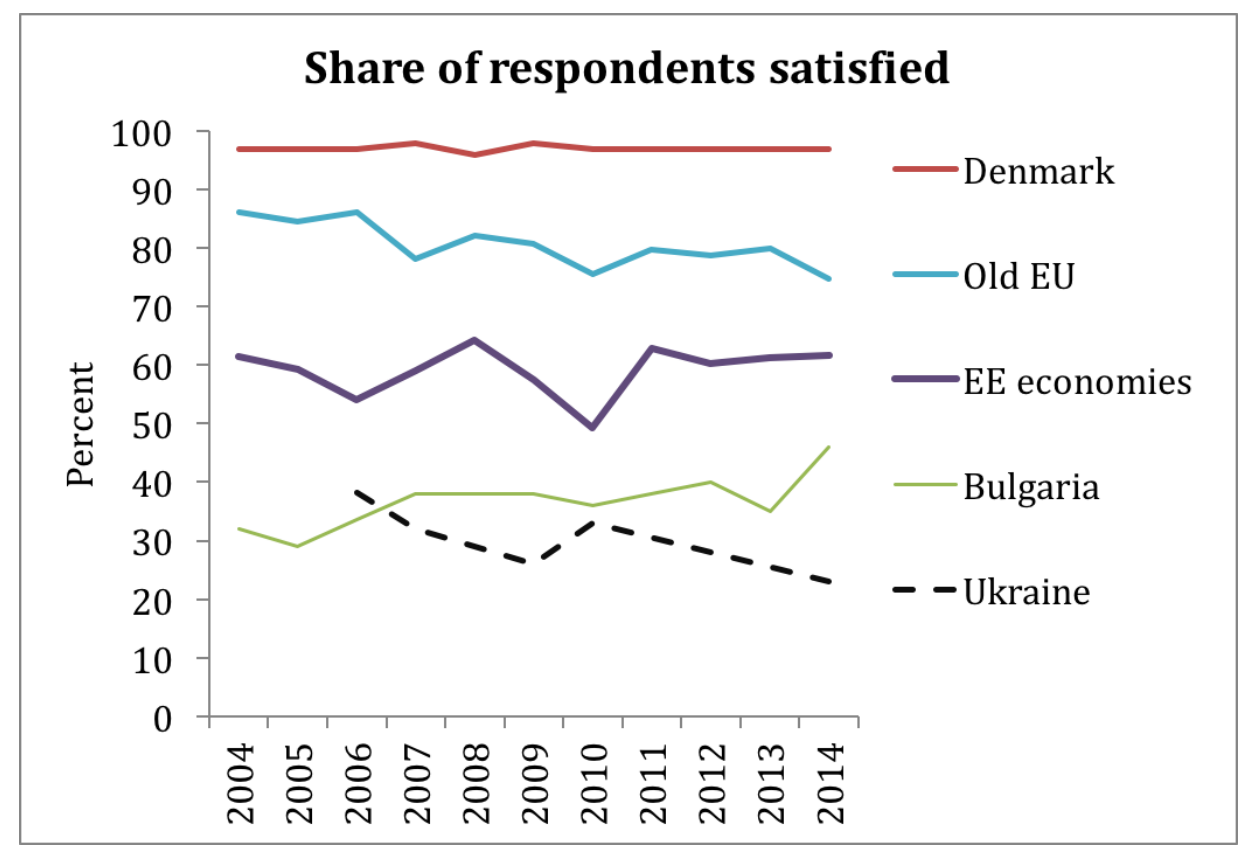

Sources: Pew Research, Eurobarometer, and Life in Transition Survey. Each survey is only included if it is available in the given year. Countries can appear in multiple surveys in the same year when the EE and Old EU aggregates are calculated. 
Figure 2: Satisfaction and log PPP GDP per capita, all countries and all periods

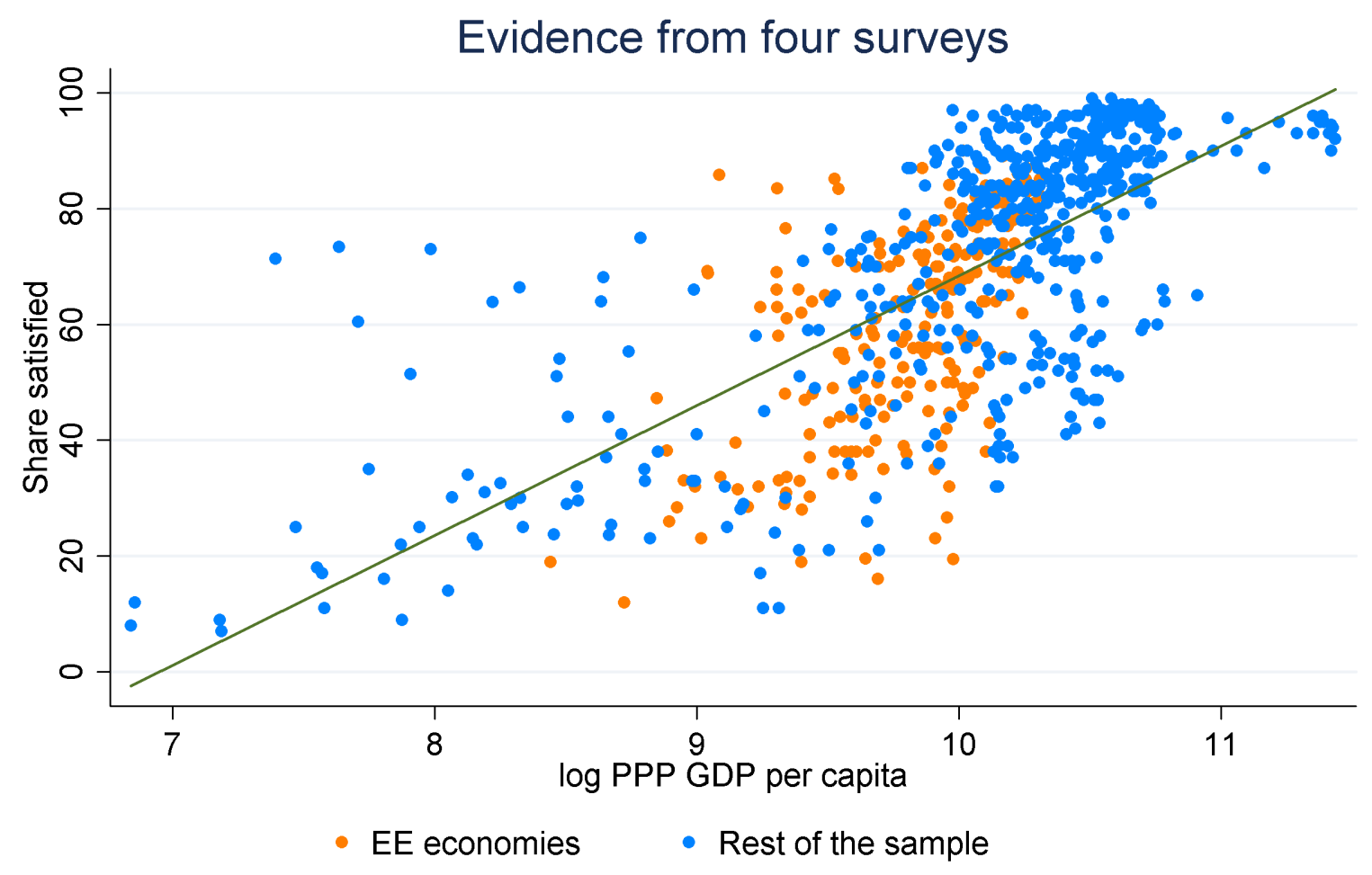

Sources: Pew Research, Eurobarometer, European Values Study, and Life in Transition Survey. 
Figure 3: Evolution of the happiness gap over time

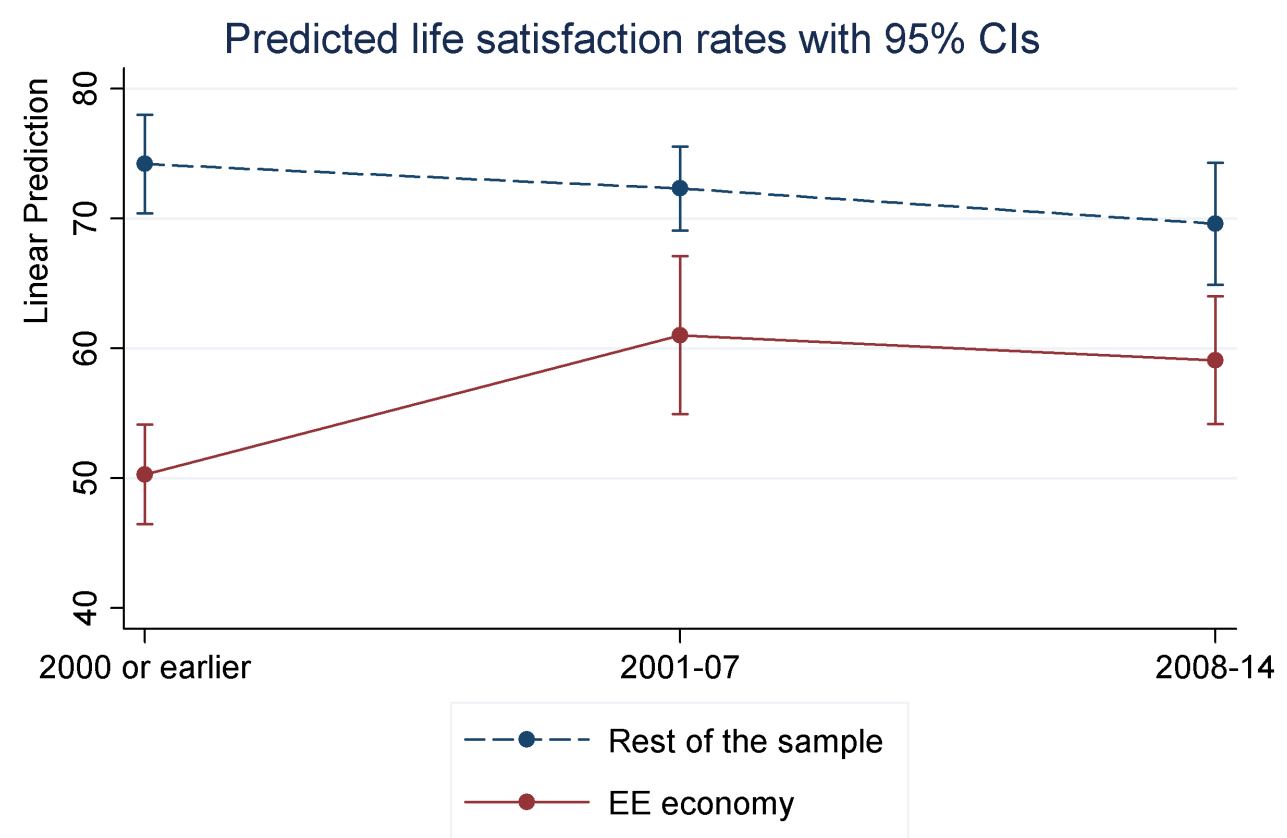

Sources: Pew Research, Eurobarometer, European Values Study, and Life in Transition Survey. 
Table 1: Summary of survey sources

\begin{tabular}{|c|c|c|c|c|c|c|c|}
\hline Country & Observations & Country & Observations & Year & Observations & Source & Observations \\
\hline Albania & 4 & Lithuania & 14 & 1989 & 1 & Pew & 132 \\
\hline Argentina & 4 & Luxembourg & 21 & 1991 & 8 & LiTS & 64 \\
\hline Armenia & 3 & Malaysia & 2 & 1994 & 12 & EB & 472 \\
\hline Austria & 20 & Malta & 12 & 1995 & 15 & EVS & 44 \\
\hline Azerbaijan & 3 & Mexico & 4 & 1996 & 15 & & \\
\hline Bangladesh & 1 & Moldova & 3 & 1997 & 15 & & \\
\hline Belarus & 3 & Mongolia & 2 & 1998 & 15 & & \\
\hline Belgium & 21 & Montenegro & 7 & 1999 & 15 & & \\
\hline Bosnia Herzegovina & 3 & Netherlands & 21 & 2000 & 15 & & \\
\hline Brazil & 2 & Nicaragua & 1 & 2001 & 15 & & \\
\hline Bulgaria & 14 & Nigeria & 2 & 2002 & 23 & & \\
\hline Chile & 2 & Norway & 1 & 2003 & 15 & & \\
\hline China & 5 & Pakistan & 5 & 2004 & 29 & & \\
\hline Colombia & 1 & Peru & 3 & 2005 & 34 & & \\
\hline Croatia & 14 & Philippines & 2 & 2006 & 58 & & \\
\hline Cyprus & 12 & Poland & 20 & 2007 & 57 & & \\
\hline Czech Republic & 14 & Portugal & 21 & 2008 & 74 & & \\
\hline Denmark & 21 & Romania & 14 & 2009 & 35 & & \\
\hline Egypt & 3 & Russia & 10 & 2010 & 86 & & \\
\hline El Salvador & 1 & Senegal & 1 & 2011 & 33 & & \\
\hline Estonia & 14 & Serbia & 6 & 2012 & 33 & & \\
\hline FYR Macedonia & 11 & Slovak Republic & 14 & 2013 & 33 & & \\
\hline Finland & 20 & Slovenia & 14 & 2014 & 76 & & \\
\hline France & 27 & South Africa & 2 & & & & \\
\hline Georgia & 3 & South Korea & 4 & & & & \\
\hline Germany & 28 & Spain & 25 & & & & \\
\hline Ghana & 3 & Sweden & 21 & & & & \\
\hline Greece & 22 & Switzerland & 1 & & & & \\
\hline Hungary & 14 & Tajikistan & 2 & & & & \\
\hline Iceland & 6 & Tanzania & 3 & & & & \\
\hline India & 1 & Thailand & 1 & & & & \\
\hline Indonesia & 3 & Tunisia & 1 & & & & \\
\hline Ireland & 21 & Turkey & 19 & & & & \\
\hline Israel & 2 & US & 7 & & & & \\
\hline Italy & 26 & Uganda & 3 & & & & \\
\hline Japan & 5 & Ukraine & 8 & & & & \\
\hline Jordan & 4 & United Kingdom & 27 & & & & \\
\hline Kazakhstan & 2 & Uzbekistan & 2 & & & & \\
\hline Kenya & 4 & Venezuela & 1 & & & & \\
\hline Kosovo & 1 & Vietnam & 1 & & & & \\
\hline Kyrgyz Republic & 2 & & & & & & \\
\hline Latvia & 14 & & & & & & \\
\hline
\end{tabular}

Sources: Pew Research, Eurobarometer, European Values Study, and Life in Transition Survey. 
Table 2: Ranking of countries by satisfaction

\begin{tabular}{|c|c|c|c|}
\hline \multicolumn{3}{|c|}{ Share happy/satisfied } & \multirow{2}{*}{$\frac{\text { Share happy/satisfied }}{55.2}$} \\
\hline Iceland & 97.8 & Greece & \\
\hline Denmark & 96.7 & Turkey & 54.1 \\
\hline Norway & 95.6 & Nicaragua & 54.0 \\
\hline Sweden & 95.1 & Albania & 53.5 \\
\hline Netherlands & 94.3 & Kazakhstan & 53.5 \\
\hline Luxembourg & 92.8 & Montenegro & 52.8 \\
\hline Switzerland & 92.8 & Chile & 52.0 \\
\hline Finland & 92.0 & Kosovo & 51.5 \\
\hline Ireland & 88.1 & South Korea & 50.5 \\
\hline Belgium & 86.8 & Mongolia & 49.6 \\
\hline Austria & 84.1 & Bosnia and Herzegovina & 49.3 \\
\hline Slovenia & 82.4 & Azerbaijan & 49.1 \\
\hline Malta & 82.1 & Hungary & 48.7 \\
\hline Cyprus & 81.4 & Romania & 47.1 \\
\hline United Kingdom & 81.3 & Malaysia & 46.0 \\
\hline Czech Republic & 77.1 & India & 44.0 \\
\hline Germany & 74.9 & Peru & 43.0 \\
\hline Spain & 74.7 & Serbia & 43.0 \\
\hline France & 74.2 & Armenia & 42.7 \\
\hline Venezuela & 74.0 & Moldova & 42.2 \\
\hline Tajikistan & 72.3 & Japan & 41.8 \\
\hline Israel & 72.0 & South Africa & 41.0 \\
\hline Estonia & 71.8 & Georgia & 39.1 \\
\hline Mexico & 71.0 & Indonesia & 38.0 \\
\hline Uzbekistan & 69.7 & Bulgaria & 38.0 \\
\hline Belarus & 69.4 & Nigeria & 36.5 \\
\hline Brazil & 69.0 & Thailand & 36.0 \\
\hline Italy & 67.5 & China & 35.2 \\
\hline Slovak Republic & 67.3 & Senegal & 35.0 \\
\hline Croatia & 67.2 & Philippines & 34.5 \\
\hline El Salvador & 66.0 & Bangladesh & 34.0 \\
\hline Colombia & 64.0 & Russia & 33.8 \\
\hline Vietnam & 64.0 & Pakistan & 31.4 \\
\hline Latvia & 61.8 & Ukraine & 31.0 \\
\hline Poland & 61.5 & Tunisia & 30.0 \\
\hline United States & 61.4 & Jordan & 27.3 \\
\hline FYR Macedonia & 59.9 & Ghana & 19.3 \\
\hline Argentina & 59.5 & Egypt & 15.7 \\
\hline Lithuania & 58.4 & Uganda & 14.7 \\
\hline Portugal & 57.5 & Kenya & 14.3 \\
\hline Kyrgyz Republic & 56.0 & Tanzania & 11.3 \\
\hline
\end{tabular}

Sources: Pew Research, Eurobarometer, European Values Study, and Life in Transition Survey. Satisfaction rates are averaged across surveys and time to arrive at a single summary measure. 
Table 3: Panel analysis of happiness gap

\begin{tabular}{|c|c|c|c|c|c|}
\hline \multicolumn{6}{|c|}{ Outcome variable: Percent satisfied } \\
\hline & (1) & (2) & (3) & (4) & $(5)$ \\
\hline & All countries & All countries & All countries & EE only & Non-EE only \\
\hline log PPP GDP per capita & $14.16^{* * *}$ & $13.87^{* * *}$ & $10.57^{* * *}$ & $27.22^{* * *}$ & $35.42^{* * *}$ \\
\hline & $(1.662)$ & $(2.923)$ & $(2.470)$ & $(8.060)$ & $(7.465)$ \\
\hline EE economy & $-10.44^{* * *}$ & $-10.34^{* * *}$ & $-7.208^{* *}$ & & \\
\hline & $(3.506)$ & $(3.344)$ & $(2.936)$ & & \\
\hline Life expectancy & & 0.0549 & 0.236 & 0.461 & -1.233 \\
\hline & & $(0.364)$ & $(0.302)$ & $(1.249)$ & $(0.866)$ \\
\hline Share orthodox & & & $\begin{array}{c}-19.02^{* * *} \\
(4.566)\end{array}$ & & \\
\hline Survey controls & $\checkmark$ & $\checkmark$ & $\checkmark$ & $\checkmark$ & $\checkmark$ \\
\hline Year fixed effects & $\checkmark$ & $\checkmark$ & $\checkmark$ & $\checkmark$ & $\checkmark$ \\
\hline Country fixed effects & & & & $\checkmark$ & $\checkmark$ \\
\hline Constant & $\begin{array}{c}-94.98^{* * *} \\
(17.25)\end{array}$ & $\begin{array}{c}-96.07^{* * *} \\
(16.40)\end{array}$ & $\begin{array}{c}-83.70^{* * *} \\
(15.37)\end{array}$ & $\begin{array}{c}-254.8^{*} \\
(126.4)\end{array}$ & $\begin{array}{c}-193.9^{* *} \\
(88.19)\end{array}$ \\
\hline Observations & 709 & 709 & 702 & 210 & 499 \\
\hline R-squared & 0.716 & 0.716 & 0.765 & 0.926 & 0.949 \\
\hline
\end{tabular}

Standard errors are in parentheses, clustered at country level. Significance levels: ${ }^{*} p<0.1,{ }^{* *} p<0.05$, ${ }^{* * *} p<0.01$. Data sources: Pew Research, Eurobarometer, European Values Study, Life in Transition Survey, IMF WEO, World Bank, and World Religion Database. 
Table 4: Life satisfaction and the quality of government

\begin{tabular}{|c|c|c|c|c|}
\hline & $(1)$ & $(2)$ & $(3)$ & $(4)$ \\
\hline log PPP GDP per capita & $\begin{array}{c}\text { Percent satisfied } \\
10.14^{* * *} \\
(2.387)\end{array}$ & $\begin{array}{c}\text { Percent satisfied } \\
5.787^{* *} \\
(2.589)\end{array}$ & $\begin{array}{c}\text { Percent satisfied } \\
10.86^{* * *} \\
(3.289)\end{array}$ & $\begin{array}{c}\text { Percent satisfied } \\
7.100^{* * *} \\
(2.561)\end{array}$ \\
\hline EE economy & $\begin{array}{c}-7.314^{* *} \\
(2.934)\end{array}$ & $\begin{array}{l}-4.774 \\
(2.878)\end{array}$ & $\begin{array}{c}-7.716^{* *} \\
(3.415)\end{array}$ & $\begin{array}{c}-5.296^{*} \\
(2.892)\end{array}$ \\
\hline Life expectancy & $\begin{array}{c}0.297 \\
(0.294)\end{array}$ & $\begin{array}{c}0.305 \\
(0.274)\end{array}$ & $\begin{array}{c}0.270 \\
(0.381)\end{array}$ & $\begin{array}{c}0.219 \\
(0.273)\end{array}$ \\
\hline Share Eastern Orthodox & $\begin{array}{c}-18.83^{* * *} \\
(4.602)\end{array}$ & $\begin{array}{c}-15.32^{* * *} \\
(4.438)\end{array}$ & $\begin{array}{c}-22.64^{* * *} \\
(5.578)\end{array}$ & $\begin{array}{c}-15.37^{* * *} \\
(4.270)\end{array}$ \\
\hline Corruption perception index & & $\begin{array}{c}0.253^{* * * *} \\
(0.0793)\end{array}$ & & \\
\hline Doing Business, average DTF of selected regulations & & & $\begin{array}{c}-0.0943 \\
(0.155)\end{array}$ & \\
\hline Government effectiveness (WGI) & & & & $\begin{array}{c}15.19^{* * *} \\
(3.692)\end{array}$ \\
\hline Regulatory quality (WGI) & & & & $\begin{array}{l}-5.485 \\
(4.591)\end{array}$ \\
\hline Rule of law (WGI) & & & & $\begin{array}{l}-5.736 \\
(4.983)\end{array}$ \\
\hline Survey controls & $\checkmark$ & $\checkmark$ & $\checkmark$ & $\checkmark$ \\
\hline Year fixed effects & $\checkmark$ & $\checkmark$ & $\checkmark$ & $\checkmark$ \\
\hline Constant & $\begin{array}{c}-70.28^{* * *} \\
(13.92)\end{array}$ & $\begin{array}{c}-43.72^{* * *} \\
(16.12)\end{array}$ & $\begin{array}{c}-70.31^{* * *} \\
(16.88)\end{array}$ & $\begin{array}{c}-41.12^{* *} \\
(19.94)\end{array}$ \\
\hline Observations & 620 & 620 & 455 & 624 \\
\hline R-squared & 0.758 & 0.775 & 0.718 & 0.774 \\
\hline
\end{tabular}

Standard errors are in parentheses, clustered at country level. Significance levels: $* p<0.1, * * p<0.05, * * *$ $p<0.01$. Data sources: Pew Research, Eurobarometer, European Values Study, Life in Transition Survey, IMF WEO, World Development Indicators, World Religion Database, World Bank's Doing Business reports, and World Governance Indicators. 
Table 5: Individual results with LiTS 2010 data

\begin{tabular}{|c|c|c|c|c|c|c|}
\hline & $\begin{array}{c}(1) \\
\text { Satisfaction }\end{array}$ & $\begin{array}{c}(2) \\
\text { Satisfaction }\end{array}$ & $\begin{array}{c}(3) \\
\text { Satisfaction }\end{array}$ & $\begin{array}{c}(4) \\
\text { Satisfaction }\end{array}$ & $\begin{array}{c}(5) \\
\text { Satisfaction }\end{array}$ & $\begin{array}{c}(6) \\
\text { Satisfaction }\end{array}$ \\
\hline log PPP GDP per capita & $\begin{array}{l}-0.169 \\
(3.734)\end{array}$ & & & & & \\
\hline EE economy & $\begin{array}{l}-20.97^{* *} \\
(9.219)\end{array}$ & & & & & \\
\hline Life expectancy & $\begin{array}{l}-0.682 \\
(0.689)\end{array}$ & & & & & \\
\hline Share Eastern Orthodox & $\begin{array}{l}-25.41^{* *} \\
(5.677)\end{array}$ & & & & & \\
\hline Health & & $\begin{array}{l}0.186^{* * *} \\
(0.014)\end{array}$ & $\begin{array}{l}0.178^{* * *} \\
(0.013)\end{array}$ & $\begin{array}{l}0.183^{* * *} \\
(0.014)\end{array}$ & $\begin{array}{l}0.173^{* * *} \\
(0.016)\end{array}$ & $\begin{array}{l}0.171^{* * *} \\
(0.016)\end{array}$ \\
\hline Married & & $\begin{array}{l}0.130^{* * *} \\
(0.016)\end{array}$ & $\begin{array}{l}0.132^{* * *} \\
(0.018)\end{array}$ & $\begin{array}{l}0.128^{* * *} \\
(0.015)\end{array}$ & $\begin{array}{l}0.125^{* * *} \\
(0.019)\end{array}$ & $\begin{array}{l}0.122^{* * *} \\
(0.018)\end{array}$ \\
\hline Age & & $\begin{array}{l}-0.025^{* * *} \\
(0.003)\end{array}$ & $\begin{array}{l}-0.026^{* * *} \\
(0.004)\end{array}$ & $\begin{array}{l}-0.024^{* * *} \\
(0.003)\end{array}$ & $\begin{array}{l}-0.025^{* * *} \\
(0.003)\end{array}$ & $\begin{array}{l}-0.025^{* * *} \\
(0.003)\end{array}$ \\
\hline $\mathrm{Age}^{2}$ & & $\begin{array}{l}0.000^{* * *} \\
(0.000)\end{array}$ & $\begin{array}{l}0.000^{* * *} \\
(0.000)\end{array}$ & $\begin{array}{l}0.000^{* * *} \\
(0.000)\end{array}$ & $\begin{array}{l}0.000^{* * *} \\
(0.000)\end{array}$ & $\begin{array}{l}0.000^{* * *} \\
(0.000)\end{array}$ \\
\hline Male & & $\begin{array}{l}0.045^{* *} \\
(0.021)\end{array}$ & $\begin{array}{l}0.046^{*} \\
(0.023)\end{array}$ & $\begin{array}{l}0.044^{*} \\
(0.022)\end{array}$ & $\begin{array}{l}0.033 \\
(0.020)\end{array}$ & $\begin{array}{l}0.035 \\
(0.022)\end{array}$ \\
\hline Secondary education & & $\begin{array}{l}0.023 \\
(0.052)\end{array}$ & $\begin{array}{l}0.039 \\
(0.052)\end{array}$ & $\begin{array}{l}0.030 \\
(0.051)\end{array}$ & $\begin{array}{l}0.042 \\
(0.048)\end{array}$ & $\begin{array}{l}0.044 \\
(0.047)\end{array}$ \\
\hline Some post-sec education & & $\begin{array}{l}0.040 \\
(0.057)\end{array}$ & $\begin{array}{l}0.065 \\
(0.055)\end{array}$ & $\begin{array}{l}0.041 \\
(0.055)\end{array}$ & $\begin{array}{l}0.061 \\
(0.054)\end{array}$ & $\begin{array}{l}0.058 \\
(0.053)\end{array}$ \\
\hline University or more & & $\begin{array}{l}0.100^{*} \\
(0.054)\end{array}$ & $\begin{array}{l}0.130^{* *} \\
(0.052)\end{array}$ & $\begin{array}{l}0.119^{* *} \\
(0.052)\end{array}$ & $\begin{array}{l}0.113^{* *} \\
(0.052)\end{array}$ & $\begin{array}{l}0.124^{* *} \\
(0.051)\end{array}$ \\
\hline Income & & $\begin{array}{l}0.217^{* * *} \\
(0.012)\end{array}$ & $\begin{array}{l}0.215^{* * *} \\
(0.013)\end{array}$ & $\begin{array}{l}0.212^{* * *} \\
(0.012)\end{array}$ & $\begin{array}{l}0.202^{* * *} \\
(0.013)\end{array}$ & $\begin{array}{l}0.199^{* * *} \\
(0.013)\end{array}$ \\
\hline Employed & & $\begin{array}{l}0.023 \\
(0.022)\end{array}$ & $\begin{array}{l}0.017 \\
(0.027)\end{array}$ & $\begin{array}{l}0.027 \\
(0.022)\end{array}$ & $\begin{array}{l}0.026 \\
(0.023)\end{array}$ & $\begin{array}{l}0.028 \\
(0.023)\end{array}$ \\
\hline Father's education & & $\begin{array}{l}-0.001 \\
(0.004)\end{array}$ & $\begin{array}{l}-0.000 \\
(0.004)\end{array}$ & $\begin{array}{l}-0.001 \\
(0.004)\end{array}$ & $\begin{array}{l}-0.002 \\
(0.004)\end{array}$ & $\begin{array}{l}-0.002 \\
(0.004)\end{array}$ \\
\hline Affected by war & & $\begin{array}{l}-0.008 \\
(0.022)\end{array}$ & $\begin{array}{l}-0.016 \\
(0.023)\end{array}$ & $\begin{array}{l}-0.004 \\
(0.022)\end{array}$ & $\begin{array}{l}-0.002 \\
(0.025)\end{array}$ & $\begin{array}{l}0.001 \\
(0.025)\end{array}$ \\
\hline Eastern Europe & & $\begin{array}{l}-0.457^{* * *} \\
(0.123)\end{array}$ & $\begin{array}{l}-0.445^{* * *} \\
(0.128)\end{array}$ & $\begin{array}{l}-0.392^{* * *} \\
(0.119)\end{array}$ & $\begin{array}{l}-0.406^{* * *} \\
(0.103)\end{array}$ & $\begin{array}{l}-0.361^{* * *} \\
(0.100)\end{array}$ \\
\hline Corruption, subjective & & & $\begin{array}{l}-0.029 \\
(0.032)\end{array}$ & & & \\
\hline Effort/ intelligence & & & & $\begin{array}{l}0.211^{* * *} \\
(0.043)\end{array}$ & & $\begin{array}{l}0.150^{* * *} \\
(0.043)\end{array}$ \\
\hline Government performance & & & & & $\begin{array}{l}0.208^{* * *} \\
(0.025)\end{array}$ & $\begin{array}{l}0.198^{* * *} \\
(0.026)\end{array}$ \\
\hline PSU geographic characteristics & & $\checkmark$ & $\checkmark$ & $\checkmark$ & $\checkmark$ & $\checkmark$ \\
\hline $\begin{array}{l}\text { Observations } \\
R^{2}\end{array}$ & $\begin{array}{l}34 \\
0.551\end{array}$ & $\begin{array}{l}24836 \\
0.224\end{array}$ & $\begin{array}{l}21069 \\
0.226\end{array}$ & $\begin{array}{l}23629 \\
0.226\end{array}$ & $\begin{array}{l}22165 \\
0.248\end{array}$ & $\begin{array}{l}21253 \\
0.249\end{array}$ \\
\hline
\end{tabular}

Notes: Column (1) replicates the specification in column (3) in Table 3 using the LiTS 2010 data only. Columns (2)-(6): Dependent variable is constructed from answer to the following question: 'All things considered, I am satisfied with my life as a whole', coded on a scale of 1 (strongly disagree) to 5 (strongly agree). OLS - Coefficients are reported. Standard errors are clustered at the country level. PSU geographic characteristics include latitude, longitude and altitude. Significance levels: * $p<0.1,{ }^{* *} p<0.05,{ }^{* * *} p<0.01$. 
Table 6: Individual results with LiTS 2010 data: Eastern European countries only

\begin{tabular}{|c|c|c|c|c|c|}
\hline & $\begin{array}{c}(1) \\
\text { Life satisfaction }\end{array}$ & $\begin{array}{c}(2) \\
\text { Life satisfaction }\end{array}$ & $\begin{array}{c}(3) \\
\text { Life satisfaction }\end{array}$ & $\begin{array}{c}(4) \\
\text { Life satisfaction }\end{array}$ & $\begin{array}{c}(5) \\
\text { Life satisfaction }\end{array}$ \\
\hline Health & $\begin{array}{l}0.180^{* * *} \\
(0.017)\end{array}$ & $\begin{array}{l}0.170^{* * *} \\
(0.015)\end{array}$ & $\begin{array}{l}0.178^{* * *} \\
(0.017)\end{array}$ & $\begin{array}{l}0.172^{* * *} \\
(0.019)\end{array}$ & $\begin{array}{l}0.169^{* * *} \\
(0.019)\end{array}$ \\
\hline Married & $\begin{array}{l}0.126^{* * *} \\
(0.019)\end{array}$ & $\begin{array}{l}0.124^{* * *} \\
(0.022)\end{array}$ & $\begin{array}{l}0.124^{* * *} \\
(0.019)\end{array}$ & $\begin{array}{l}0.121^{* * *} \\
(0.022)\end{array}$ & $\begin{array}{l}0.119^{* * *} \\
(0.022)\end{array}$ \\
\hline Age & $\begin{array}{l}-0.021^{* * *} \\
(0.003)\end{array}$ & $\begin{array}{l}-0.021^{* * *} \\
(0.003)\end{array}$ & $\begin{array}{l}-0.020^{* * *} \\
(0.003)\end{array}$ & $\begin{array}{l}-0.021^{* * *} \\
(0.003)\end{array}$ & $\begin{array}{l}-0.020^{* * *} \\
(0.003)\end{array}$ \\
\hline $\mathrm{Age}^{2}$ & $\begin{array}{l}0.000^{* * *} \\
(0.000)\end{array}$ & $\begin{array}{l}0.000^{* * *} \\
(0.000)\end{array}$ & $\begin{array}{l}0.000^{* * *} \\
(0.000)\end{array}$ & $\begin{array}{l}0.000^{* * *} \\
(0.000)\end{array}$ & $\begin{array}{l}0.000^{* * *} \\
(0.000)\end{array}$ \\
\hline Male & $\begin{array}{l}0.055^{* *} \\
(0.021)\end{array}$ & $\begin{array}{l}0.058^{* *} \\
(0.024)\end{array}$ & $\begin{array}{l}0.054^{* *} \\
(0.023)\end{array}$ & $\begin{array}{l}0.039^{*} \\
(0.021)\end{array}$ & $\begin{array}{l}0.041^{*} \\
(0.022)\end{array}$ \\
\hline Secondary education & $\begin{array}{l}0.012 \\
(0.052)\end{array}$ & $\begin{array}{l}0.025 \\
(0.052)\end{array}$ & $\begin{array}{l}0.020 \\
(0.052)\end{array}$ & $\begin{array}{l}0.025 \\
(0.047)\end{array}$ & $\begin{array}{l}0.027 \\
(0.047)\end{array}$ \\
\hline Some post-sec education & $\begin{array}{l}0.021 \\
(0.058)\end{array}$ & $\begin{array}{l}0.043 \\
(0.056)\end{array}$ & $\begin{array}{l}0.023 \\
(0.058)\end{array}$ & $\begin{array}{l}0.039 \\
(0.056)\end{array}$ & $\begin{array}{l}0.036 \\
(0.056)\end{array}$ \\
\hline University or more & $\begin{array}{l}0.092 \\
(0.055)\end{array}$ & $\begin{array}{l}0.124^{* *} \\
(0.053)\end{array}$ & $\begin{array}{l}0.114^{* *} \\
(0.055)\end{array}$ & $\begin{array}{l}0.109^{*} \\
(0.054)\end{array}$ & $\begin{array}{l}0.121^{* *} \\
(0.054)\end{array}$ \\
\hline Income & $\begin{array}{l}0.235^{* * *} \\
(0.010)\end{array}$ & $\begin{array}{l}0.235^{* * *} \\
(0.010)\end{array}$ & $\begin{array}{l}0.230^{* * *} \\
(0.010)\end{array}$ & $\begin{array}{l}0.220^{* * *} \\
(0.011)\end{array}$ & $\begin{array}{l}0.218^{* * *} \\
(0.011)\end{array}$ \\
\hline Employed & $\begin{array}{l}0.026 \\
(0.023)\end{array}$ & $\begin{array}{l}0.016 \\
(0.028)\end{array}$ & $\begin{array}{l}0.030 \\
(0.023)\end{array}$ & $\begin{array}{l}0.030 \\
(0.024)\end{array}$ & $\begin{array}{l}0.033 \\
(0.024)\end{array}$ \\
\hline Father's education & $\begin{array}{l}-0.004 \\
(0.004)\end{array}$ & $\begin{array}{l}-0.004 \\
(0.004)\end{array}$ & $\begin{array}{l}-0.004 \\
(0.004)\end{array}$ & $\begin{array}{l}-0.005 \\
(0.004)\end{array}$ & $\begin{array}{l}-0.005 \\
(0.004)\end{array}$ \\
\hline Affected by war & $\begin{array}{l}0.016 \\
(0.023)\end{array}$ & $\begin{array}{l}0.013 \\
(0.024)\end{array}$ & $\begin{array}{l}0.020 \\
(0.023)\end{array}$ & $\begin{array}{l}0.019 \\
(0.028)\end{array}$ & $\begin{array}{l}0.022 \\
(0.027)\end{array}$ \\
\hline Corruption, subjective & & $\begin{array}{l}-0.038 \\
(0.032)\end{array}$ & & & \\
\hline Effort/ intelligence & & & $\begin{array}{l}0.181^{* * *} \\
(0.042)\end{array}$ & & $\begin{array}{l}0.123^{* * *} \\
(0.044)\end{array}$ \\
\hline Government performance & & & & $\begin{array}{l}0.201^{* * *} \\
(0.027)\end{array}$ & $\begin{array}{l}0.194^{* * *} \\
(0.028)\end{array}$ \\
\hline PSU geographic characteristics & $\checkmark$ & $\checkmark$ & $\checkmark$ & $\checkmark$ & $\checkmark$ \\
\hline $\begin{array}{l}\text { Observations } \\
R^{2}\end{array}$ & $\begin{array}{l}20649 \\
0.189\end{array}$ & $\begin{array}{l}17037 \\
0.186\end{array}$ & $\begin{array}{l}19603 \\
0.190\end{array}$ & $\begin{array}{l}18202 \\
0.212\end{array}$ & $\begin{array}{l}17428 \\
0.214\end{array}$ \\
\hline
\end{tabular}

Notes: Dependent variable is constructed from answer to the following question: 'All things considered, I am satisfied with my life as a whole', coded on a scale of 1 (strongly disagree) to 5 (strongly agree). OLS - Coefficients are reported. Standard errors are clustered at the country level. PSU geographic characteristics include latitude, longitude and altitude. Significance levels: * $p<0.1,{ }^{* *} p<0.05, * * * p<0.01$. 
Table 7: Individual results with LiTS 2010 data: Non-Eastern European countries only

\begin{tabular}{|c|c|c|c|c|c|}
\hline & $\stackrel{(1)}{\text { Life satisfaction }}$ & $\begin{array}{c}(2) \\
\text { Life satisfaction }\end{array}$ & $\begin{array}{c}(3) \\
\text { Life satisfaction }\end{array}$ & $\begin{array}{c}(4) \\
\text { Life satisfaction }\end{array}$ & $\begin{array}{c}(5) \\
\text { Life satisfaction }\end{array}$ \\
\hline Health & $\begin{array}{l}0.176^{* * *} \\
(0.035)\end{array}$ & $\begin{array}{l}0.168^{* * *} \\
(0.034)\end{array}$ & $\begin{array}{l}0.170^{* *} \\
(0.039)\end{array}$ & $\begin{array}{l}0.153^{* *} \\
(0.036)\end{array}$ & $\begin{array}{l}0.151^{* *} \\
(0.039)\end{array}$ \\
\hline Married & $\begin{array}{l}0.131^{* * *} \\
(0.018)\end{array}$ & $\begin{array}{l}0.147^{* * *} \\
(0.014)\end{array}$ & $\begin{array}{l}0.126^{* * *} \\
(0.012)\end{array}$ & $\begin{array}{l}0.130^{* * *} \\
(0.014)\end{array}$ & $\begin{array}{l}0.119^{* * *} \\
(0.013)\end{array}$ \\
\hline Age & $\begin{array}{l}-0.032^{* *} \\
(0.011)\end{array}$ & $\begin{array}{l}-0.034^{* *} \\
(0.012)\end{array}$ & $\begin{array}{l}-0.033^{* *} \\
(0.011)\end{array}$ & $\begin{array}{l}-0.032^{* *} \\
(0.011)\end{array}$ & $\begin{array}{l}-0.034^{* *} \\
(0.010)\end{array}$ \\
\hline $\mathrm{Age}^{2}$ & $\begin{array}{l}0.000^{* *} \\
(0.000)\end{array}$ & $\begin{array}{l}0.000^{* *} \\
(0.000)\end{array}$ & $\begin{array}{l}0.000^{* *} \\
(0.000)\end{array}$ & $\begin{array}{l}0.000^{* *} \\
(0.000)\end{array}$ & $\begin{array}{l}0.000^{* *} \\
(0.000)\end{array}$ \\
\hline Male & $\begin{array}{l}0.030 \\
(0.027)\end{array}$ & $\begin{array}{l}0.031 \\
(0.032)\end{array}$ & $\begin{array}{l}0.028 \\
(0.032)\end{array}$ & $\begin{array}{l}0.027 \\
(0.029)\end{array}$ & $\begin{array}{l}0.025 \\
(0.037)\end{array}$ \\
\hline Secondary education & $\begin{array}{l}0.105 \\
(0.112)\end{array}$ & $\begin{array}{l}0.129 \\
(0.114)\end{array}$ & $\begin{array}{l}0.102 \\
(0.104)\end{array}$ & $\begin{array}{l}0.148 \\
(0.108)\end{array}$ & $\begin{array}{l}0.144 \\
(0.104)\end{array}$ \\
\hline Some post-sec education & $\begin{array}{l}0.166 \\
(0.129)\end{array}$ & $\begin{array}{l}0.181 \\
(0.130)\end{array}$ & $\begin{array}{l}0.153 \\
(0.103)\end{array}$ & $\begin{array}{l}0.195 \\
(0.112)\end{array}$ & $\begin{array}{l}0.183 \\
(0.093)\end{array}$ \\
\hline University or more & $\begin{array}{l}0.173 \\
(0.125)\end{array}$ & $\begin{array}{l}0.195 \\
(0.123)\end{array}$ & $\begin{array}{l}0.180 \\
(0.093)\end{array}$ & $\begin{array}{l}0.187 \\
(0.114)\end{array}$ & $\begin{array}{l}0.198^{*} \\
(0.089)\end{array}$ \\
\hline Income & $\begin{array}{l}0.140^{* *} \\
(0.037)\end{array}$ & $\begin{array}{l}0.140^{* *} \\
(0.039)\end{array}$ & $\begin{array}{l}0.133^{* *} \\
(0.033)\end{array}$ & $\begin{array}{l}0.130^{* *} \\
(0.038)\end{array}$ & $\begin{array}{l}0.122^{* *} \\
(0.036)\end{array}$ \\
\hline Employed & $\begin{array}{l}0.081^{*} \\
(0.031)\end{array}$ & $\begin{array}{l}0.090^{*} \\
(0.036)\end{array}$ & $\begin{array}{l}0.078^{* *} \\
(0.026)\end{array}$ & $\begin{array}{l}0.053 \\
(0.034)\end{array}$ & $\begin{array}{l}0.055 \\
(0.031)\end{array}$ \\
\hline Father's education & $\begin{array}{l}0.007 \\
(0.006)\end{array}$ & $\begin{array}{l}0.009 \\
(0.006)\end{array}$ & $\begin{array}{l}0.005 \\
(0.007)\end{array}$ & $\begin{array}{l}0.008 \\
(0.006)\end{array}$ & $\begin{array}{l}0.007 \\
(0.007)\end{array}$ \\
\hline Affected by war & $\begin{array}{l}-0.056 \\
(0.027)\end{array}$ & $\begin{array}{l}-0.062^{*} \\
(0.026)\end{array}$ & $\begin{array}{l}-0.053 \\
(0.029)\end{array}$ & $\begin{array}{l}-0.050 \\
(0.031)\end{array}$ & $\begin{array}{l}-0.047 \\
(0.035)\end{array}$ \\
\hline Corruption, subjective & & $\begin{array}{l}-0.027 \\
(0.016)\end{array}$ & & & \\
\hline Effort/ intelligence & & & $\begin{array}{l}0.390^{* * *} \\
(0.034)\end{array}$ & & $\begin{array}{l}0.339^{* * *} \\
(0.037)\end{array}$ \\
\hline Government performance & & & & $\begin{array}{l}0.199^{* * *} \\
(0.018)\end{array}$ & $\begin{array}{l}0.178^{* * *} \\
(0.019)\end{array}$ \\
\hline PSU geographic characteristics & $\checkmark$ & $\checkmark$ & $\checkmark$ & $\checkmark$ & $\checkmark$ \\
\hline $\begin{array}{l}\text { Observations } \\
R^{2}\end{array}$ & $\begin{array}{l}4187 \\
0.208\end{array}$ & $\begin{array}{l}4032 \\
0.213\end{array}$ & $\begin{array}{l}4026 \\
0.224\end{array}$ & $\begin{array}{l}3963 \\
0.230\end{array}$ & $\begin{array}{l}3825 \\
0.242\end{array}$ \\
\hline
\end{tabular}

Notes: Dependent variable is constructed from answer to the following question: 'All things considered, I am satisfied with my life as a whole', coded on a scale of 1 (strongly disagree) to 5 (strongly agree). OLS - Coefficients are reported. Standard errors are clustered at the country level. PSU geographic characteristics include latitude, longitude and altitude. Significance levels: ${ }^{*} p<0.1,{ }^{* *} p<0.05,{ }^{* * *} p<0.01$. 
Table 8: Life satisfaction and public-sector corruption: cross-country results

\begin{tabular}{|c|c|c|c|c|}
\hline & (1) & (2) & (3) & (4) \\
\hline log PPP GDP per capita & $\begin{array}{c}\text { Percent satisfied } \\
12.38^{* * *} \\
(1.812)\end{array}$ & $\begin{array}{c}\text { Percent satisfied } \\
8.873^{* * *} \\
(2.705)\end{array}$ & $\begin{array}{c}\text { Percent satisfied } \\
12.35^{* * *} \\
(3.494)\end{array}$ & $\begin{array}{c}\text { Percent satisfied } \\
11.23^{* * *} \\
(3.149)\end{array}$ \\
\hline EE economy & $\begin{array}{c}-12.64^{* * *} \\
(3.560)\end{array}$ & $\begin{array}{c}-7.916^{* *} \\
(3.125)\end{array}$ & $\begin{array}{r}-8.573^{*} \\
(4.323)\end{array}$ & $\begin{array}{l}-5.641 \\
(4.076)\end{array}$ \\
\hline Life expectancy & & $\begin{array}{c}0.254 \\
(0.306)\end{array}$ & & $\begin{array}{l}-0.224 \\
(0.423)\end{array}$ \\
\hline Share Orthodox & & $\begin{array}{c}-22.61^{* * *} \\
(5.025)\end{array}$ & & $\begin{array}{c}-19.98^{* * *} \\
(5.477)\end{array}$ \\
\hline Paid bribe & & & $\begin{array}{l}-0.110 \\
(0.166)\end{array}$ & $\begin{array}{l}-0.171 \\
(0.183)\end{array}$ \\
\hline Survey controls & $\checkmark$ & $\checkmark$ & $\checkmark$ & $\checkmark$ \\
\hline Year fixed effects & $\checkmark$ & $\checkmark$ & $\checkmark$ & $\checkmark$ \\
\hline Observations & 194 & 192 & 139 & 137 \\
\hline R-squared & 0.625 & 0.694 & 0.594 & 0.657 \\
\hline
\end{tabular}

Standard errors are in parentheses, clustered at country level. Significance levels: $* p<0.1, * * p<0.05, * * * p<0.01$. The sample consists only of the post-2009 waves of Pew, Eurobarometer, and LiTS. Other data sources: IMF WEO, World Development Indicators, World Religion Database, World Bank's Doing Business reports, and Transparency International's Global Corruption Barometer. 
Table 9: Individual results: Bulgaria, LiTS 2006

\begin{tabular}{|c|c|c|c|c|c|}
\hline & $\begin{array}{c}(1) \\
\text { Life satisfaction }\end{array}$ & $\begin{array}{c}(2) \\
\text { Life satisfaction }\end{array}$ & $\begin{array}{c}(3) \\
\text { Life satisfaction }\end{array}$ & $\begin{array}{c}(4) \\
\text { Life satisfaction }\end{array}$ & $\begin{array}{c}(5) \\
\text { Life satisfaction }\end{array}$ \\
\hline Health & $\begin{array}{l}0.181^{* * *} \\
(0.048)\end{array}$ & $\begin{array}{l}0.200^{* * *} \\
(0.045)\end{array}$ & $\begin{array}{l}0.181^{* * *} \\
(0.046)\end{array}$ & $\begin{array}{l}0.182^{* * *} \\
(0.045)\end{array}$ & $\begin{array}{l}0.156^{* * *} \\
(0.047)\end{array}$ \\
\hline Age & $\begin{array}{l}-0.045^{* * *} \\
(0.014)\end{array}$ & $\begin{array}{l}-0.038^{* * *} \\
(0.014)\end{array}$ & $\begin{array}{l}-0.040^{* * *} \\
(0.014)\end{array}$ & $\begin{array}{l}-0.034^{* *} \\
(0.014)\end{array}$ & $\begin{array}{l}-0.037^{* * *} \\
(0.014)\end{array}$ \\
\hline $\mathrm{Age}^{2}$ & $\begin{array}{l}0.000^{* * *} \\
(0.000)\end{array}$ & $\begin{array}{l}0.000^{* *} \\
(0.000)\end{array}$ & $\begin{array}{l}0.000^{* * *} \\
(0.000)\end{array}$ & $\begin{array}{l}0.000^{* *} \\
(0.000)\end{array}$ & $\begin{array}{l}0.000^{* *} \\
(0.000)\end{array}$ \\
\hline Male & $\begin{array}{l}0.184^{* *} \\
(0.076)\end{array}$ & $\begin{array}{l}0.147^{* *} \\
(0.072)\end{array}$ & $\begin{array}{l}0.175^{* *} \\
(0.074)\end{array}$ & $\begin{array}{l}0.149^{* *} \\
(0.071)\end{array}$ & $\begin{array}{l}0.182^{* *} \\
(0.073)\end{array}$ \\
\hline Secondary education & $\begin{array}{l}0.033 \\
(0.100)\end{array}$ & $\begin{array}{l}0.098 \\
(0.094)\end{array}$ & $\begin{array}{l}0.051 \\
(0.096)\end{array}$ & $\begin{array}{l}0.085 \\
(0.094)\end{array}$ & $\begin{array}{l}0.021 \\
(0.097)\end{array}$ \\
\hline Some post-sec education & $\begin{array}{l}0.161 \\
(0.128)\end{array}$ & $\begin{array}{l}0.243^{* *} \\
(0.123)\end{array}$ & $\begin{array}{l}0.188 \\
(0.123)\end{array}$ & $\begin{array}{l}0.212^{*} \\
(0.121)\end{array}$ & $\begin{array}{l}0.127 \\
(0.124)\end{array}$ \\
\hline University or more & $\begin{array}{l}0.688^{*} \\
(0.353)\end{array}$ & $\begin{array}{l}0.702^{* *} \\
(0.327)\end{array}$ & $\begin{array}{l}0.847^{* * *} \\
(0.312)\end{array}$ & $\begin{array}{l}0.715^{* *} \\
(0.299)\end{array}$ & $\begin{array}{l}0.660^{* *} \\
(0.320)\end{array}$ \\
\hline Income & $\begin{array}{l}0.119^{* * *} \\
(0.024)\end{array}$ & $\begin{array}{l}0.165^{* * *} \\
(0.022)\end{array}$ & $\begin{array}{l}0.117^{* * *} \\
(0.023)\end{array}$ & $\begin{array}{l}0.153^{* * *} \\
(0.022)\end{array}$ & $\begin{array}{l}0.115^{* * *} \\
(0.023)\end{array}$ \\
\hline Employed & $\begin{array}{l}0.220^{* *} \\
(0.096)\end{array}$ & $\begin{array}{l}0.163^{*} \\
(0.093)\end{array}$ & $\begin{array}{l}0.168^{*} \\
(0.094)\end{array}$ & $\begin{array}{l}0.155^{*} \\
(0.092)\end{array}$ & $\begin{array}{l}0.201^{* *} \\
(0.093)\end{array}$ \\
\hline Father's education & $\begin{array}{l}0.065 \\
(0.044)\end{array}$ & $\begin{array}{l}0.050 \\
(0.042)\end{array}$ & $\begin{array}{l}0.070 \\
(0.043)\end{array}$ & $\begin{array}{l}0.058 \\
(0.041)\end{array}$ & $\begin{array}{l}0.071^{*} \\
(0.043)\end{array}$ \\
\hline Corruption, objective & $\begin{array}{l}-0.158^{* *} \\
(0.062)\end{array}$ & & & & $\begin{array}{l}-0.219^{* * *} \\
(0.059)\end{array}$ \\
\hline Corruption, subjective & & $\begin{array}{l}-0.314^{* * *} \\
(0.047)\end{array}$ & & $\begin{array}{l}-0.262^{* * *} \\
(0.046)\end{array}$ & \\
\hline Effort/ intelligence & & & $\begin{array}{l}0.514^{* * *} \\
(0.077)\end{array}$ & $\begin{array}{l}0.443^{* * *} \\
(0.075)\end{array}$ & $\begin{array}{l}0.507^{* * *} \\
(0.079)\end{array}$ \\
\hline PSU geographic characteristics & $\checkmark$ & $\checkmark$ & $\checkmark$ & $\checkmark$ & $\checkmark$ \\
\hline Oblast dummies & $\checkmark$ & $\checkmark$ & $\checkmark$ & $\checkmark$ & $\checkmark$ \\
\hline $\begin{array}{l}\text { Observations } \\
R^{2}\end{array}$ & $\begin{array}{l}880 \\
0.290\end{array}$ & $\begin{array}{l}929 \\
0.323\end{array}$ & $\begin{array}{l}907 \\
0.326\end{array}$ & $\begin{array}{l}907 \\
0.352\end{array}$ & $\begin{array}{l}871 \\
0.330\end{array}$ \\
\hline
\end{tabular}

Notes: Dependent variable is constructed from answer to the following question: 'All things considered, I am satisfied with my life as a whole', coded on a scale of 1 (strongly disagree) to 5 (strongly agree). OLS - Coefficients are reported. PSU geographic characteristics include latitude and longitude. Robust standard errors are in parentheses. Significance levels: ${ }^{*} p<0.1, * *$ $p<0.05,{ }^{* * *} p<0.01$. 